CAMP Working Paper Series

No $9 / 2016$

\title{
Mending the broken link: heterogeneous bank lending and monetary policy pass-through.
}

Carlo Altavilla, Fabio Canova and Matteo Ciccarelli

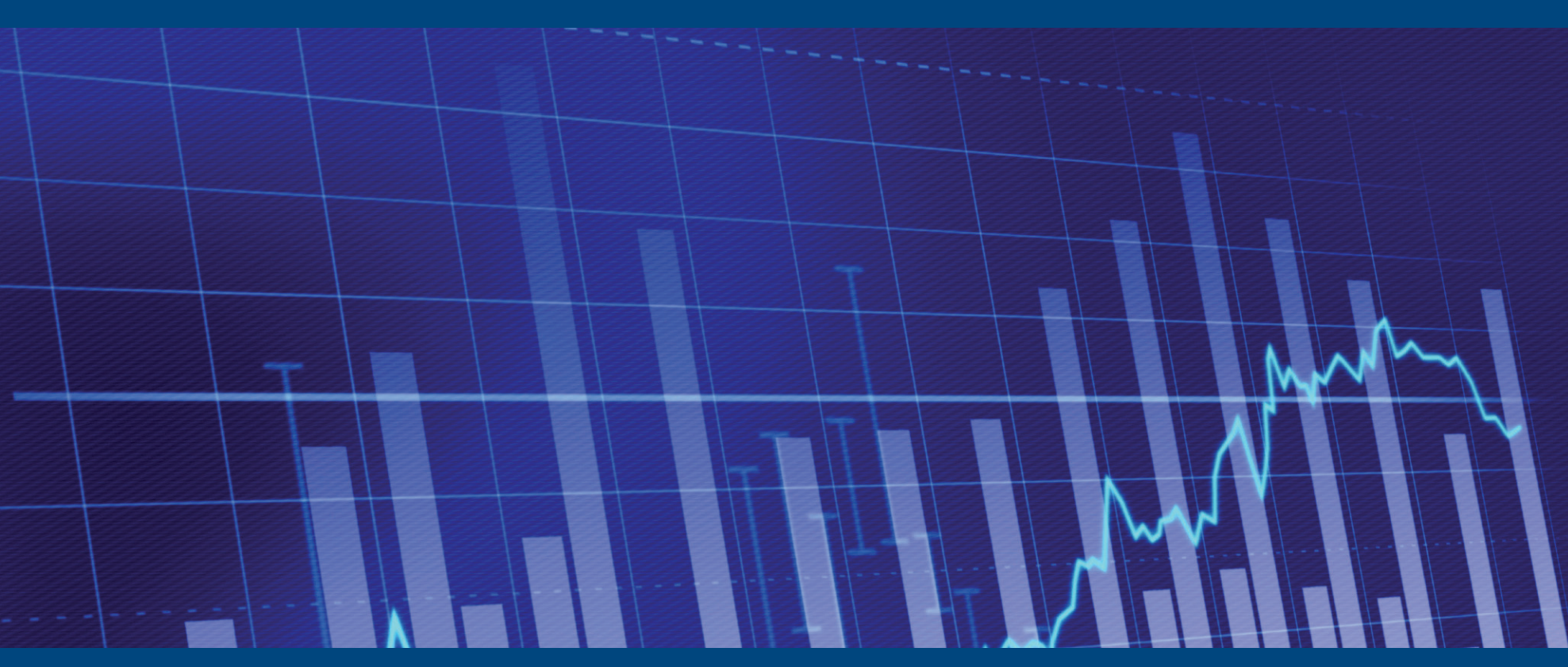

(C) Authors 2016

This paper can be downloaded without charge from the CAMP website http://www.bi.no/camp 


\title{
Mending the broken link: heterogeneous bank lending and monetary policy pass-through.
}

\author{
Carlo Altavilla, \\ ECB*
}

\author{
Fabio Canova, \\ Norwegian Business School ${ }^{\dagger}$
}

October 31, 2016

\author{
Matteo Ciccarelli, \\ $\mathrm{ECB}^{\ddagger}$
}

\begin{abstract}
We analyze the pass-through of monetary policy measures to lending rates to firms and households in the euro area using a novel bank-level dataset. Banks' characteristics such as the capital ratio, the exposure to sovereign debt, and the percentage of non-performing loans are responsible for the heterogeneity in pass-through of conventional monetary policy changes. The location of a bank is irrelevant. Non-standard measures normalized the capacity of banks to grant loans. Banks with high level of non-performing loans and low capital ratio were most affected. Banks' lending margins fell considerably. Macroeconomic implications are discussed.
\end{abstract}

JEL Classification numbers: C23, E44, E52, G21.

Keywords: Monetary policy pass-through, european banks, heterogeneity, VARs.

\footnotetext{
*European Central Bank, Sonnemannstrasse 22,60314 Frankfurt, Germany; email: carlo.altavilla@ecb.europa.eu

${ }^{\dagger}$ Corresponding author, Norwegian Business School, CAMP, and CEPR. Department of Economics, BI Norwegian Business School, Nydalsveien 37, 0484 Oslo, Norway; email: fabio.canova@bi.no

${ }^{\ddagger}$ European Central Bank, Sonnemannstrasse 22, 60314 Frankfurt, Germany; email matteo.ciccarelli@ecb.europa.eu.
} 


\section{Introduction}

Lending conditions are crucial to the level of economic activity and welfare. This is particularly true in the euro area since bank loans are around $50 \%$ of the external balance sheet financing of both small and large non-financial corporations - in the U.S. bank loans account for only around $25 \%$. If firms face working capital and wage bill constraints, impairment of lending activities constrains hiring and investment decisions and, thus, the level of aggregate activity.

Lending conditions also matter for monetary policy: an ineffective pass-through of policy rate changes makes it much harder for a central bank to regulate the dynamics of aggregate demand. From the early 2000s to the end of 2007, monetary policy pass-through in the euro area was relatively homogeneous across countries (see e.g. Ciccarelli et al. 2013) and almost complete in the long run (see Hristov et al. 2014). During the financial and the sovereign debt crises, the situation changed. Figure 1 shows the policy rate and the distribution of lending rates to non-financial corporations for the collection of banks in our data set for the period July 2007 - December 2015, normalised so that the policy rate is set to zero in July 2007.

There are four distinct phases. Up to the end of 2008, the distribution of lending rates followed the dynamics of the policy rate and the spread of the cross-sectional distribution was small. From the beginning of 2009 to the middle of 2011, the median of the distribution of lending rates continued to follow policy rate changes, but the spread in the distribution increased. In the third phase, the median of the lending rates distribution no longer follows policy rate changes, especially for banks operating in financially stressed countries - we term "stressed countries" Greece, Cyprus, Italy, Spain, Ireland and Portugal, while the "non-stressed countries" are Austria, France, Germany, Netherlands, Belgium and Luxembourg. In this period, lending rate heterogeneity became considerable and different banks reacted differently to monetary policy changes, even within each group of countries. For example, between September 2011 and May 2014, the range of the distribution of lending rates in non-stressed countries increased one percentage point, while the median fell from 3.2 to 2.3 percent. From May 2014 onwards, both the median and the spread of the lending rate distribution accompanied policy rate declines and the fall was considerable for stressed countries. These patterns beg obvious questions: Why did the pass-through change during the period of financial turmoil? Why did different banks respond differently to monetary policy changes? Why was the pattern reversed after 2014? Which feature of monetary policy was responsible for the change?

The conventional view in normal times is that balance sheet characteristics determine how banks react to monetary policy contractions. In the US, the pass-through to lending rates has 
been found to be stronger for small (Kashyap and Stein, 1995), illiquid (Stein, 1998; Kashyap and Stein, 2000) and poorly capitalised banks (Peek and Rosengren, 1995; Kishan and Opiela, 2000; Van den Heuvel, 2002). Gambacorta $(2005,2008)$ confirms these findings using a sample of Italian banks. Larger, better capitalised, and more liquid banks are more resilient to monetary contractions as they can more easily substitute sources of external financing, absorb expected future losses, and divert liquidity to satisfy increases in loan demand. Contractionary policy decisions are thus transmitted to the real economy mainly through small, illiquid, and poorly capitalised banks. In closed economies where firms externally finance a large portion of their operations through banks with a weak balance sheet position, monetary contractions are a powerful brake on domestic real activity.

In periods of financial stress, economic and regulatory constraints might alter the effectiveness of monetary policy. In addition, and apart from two brief episodes, monetary policy in the euro area in the period of interest was expansionary and it is unclear as yet whether banks respond in the same way to expansionary and to contractionary policy changes. Recent work analysing the pass-through during the last decade in the euro area has produced contradictory conclusions. For example, Hristov et al. (2014), and Holton and Rodriguez d'Acri (2015) document a significant fall in the average pass-through relative to the pre-crisis period, while Von Borstel et al. (2015), Illes et al. (2015) only find a mild decline which is statistically similar in core and periphery countries, once banks' effective cost of funding is taken into account. Thus, variations in passthrough are attributed to area-wide structural changes. Jimenez et al. (2012), Acharya et al. (2015), on the other hand, find that the health of banks' balance sheet affect their portfolio choices (see also Acharya and Steffen, 2015, Altavilla et al., 2016, and Acharya et al., 2016) and thus the transmission of monetary policy changes.

This paper re-examines the monetary pass-through to lending rates in the euro area during the turbulent 2007-2015 period using a novel monthly disaggregated data set. Contrary to previous work, which has used banks from one country only, a limited number of European banks, or country aggregates of bank data, our data set is very rich. We have information on the major euro area banks, covering about $75 \%$ of the total; we know their locations and a number of their balance sheet characteristics and this help us to avoid cross-sectional or cross country heterogeneity biases. Furthermore, the sample is sufficiently long to meaningfully distinguish between the pass-through of conventional and non-standard policy decisions, and to measure the contribution of the latter to normalising lending conditions.

We first examine how persistent policy rate surprises affect the quartiles of the distribution of the lending rates to non-financial corporations for the period up to May 2014 - we call this 
conventional policy pass-through. We show that, once country-specific factors are taken into account, the distinction between stressed and non-stressed countries is irrelevant and the median medium run pass-through for both types of countries is only around 0.6, much lower than in the early 2000s, and close to the estimates obtained using aggregated country data. Instead, for the period and for the collection of banks we consider, we find that bank balance sheet characteristics matter. In particular, the level of capitalisation and the exposure to sovereign debt are robust determinants of the spread of the distribution of pass-through. We estimate that the difference between the top and the bottom quartiles of the distribution of lending rates pass-through sorted by these characteristics could be up to 50 basis points. The composition of a bank's portfolio and its expected losses also help to explain the dynamics and the spread in the distribution of the monetary pass-through for large banks. Interestingly, these conclusions hold when we consider both lending rates to non-financial corporations and to households.

In the second part, we examine the pass-through of non-standard policies. Since June 2014, the ECB employed credit easing measures - the targeted longer-term refinancing operations (TLTROs) - to "enhance the transmission of monetary policy and to reinforce the accommodative monetary policy stance in view of the (...) subdued monetary and credit dynamics" (ECB Economic Bulletin, October 2015). In January 2015, it also announced quantitative easing measures - the expanded asset purchase programme (APP) - to further ease monetary policy given that the policy rate had hit the zero lower bound and prospects for the real economy had deteriorated since the introduction of the credit easing package (see Altavilla et al., 2015).

We show that these measures helped to normalise lending conditions, reduce the crosssectional dispersion of lending rates and produce a larger pass-through in the medium run. Better lending conditions for non-financial corporations materialised because the instantaneous pass-through improved and because of dynamic funding cost relief and signalling effects. Banks with a high level of non-performing loans and a low capital share were the most responsive to the measures and banks with higher uptakes in the credit easing operations reduced lending rates more than banks not participating in the program. Non-standard measures also contributed to normalise the dynamics of lending rates to households. It is well known that the pass-through of standard policy measures to household lending rates is generally lower than that to non-financial corporations, and that non-competitive pricing features explain this difference. Even though the effect is smaller, lending rates to households also fell in response to non-standard measures and banks with a high level of non-performing loans and a low level of capital responded most.

Non-standard measures compressed banks' lending margins significantly. When pricing frictions are present, monetary policy may alter lending margins (Gambacorta, 2008; Alessandri 
and Nelson, 2015). Changes in lending margins, in turn, might change the returns from maturity transformation activities with adverse effects on their profitability and their market value. We find that the compression of lending margins is larger for banks with a low level of capital, a higher exposure to sovereign debt, and a higher share of non-performing loans. Thus, while non-standard measures decreased funding costs for a class of banks, they hampered a component of their profitability, potentially making the banking system vulnerable to shocks.

We quantify the implications of standard and non-standard policies on the output gap and inflation using a workhorse macroeconomic model. We show that, by December 2015 and absent non-standard measures, inflation would have been 0.6 percent lower and the output gap 0.5 percent higher than actually recorded. We also find that the dynamics of the output gap and inflation that non-standard policies generate would have been insignificantly different from those obtained with a counterfactual perfect pass-through.

The rest of the paper is organised as follows. Section 2 provides a discussion of the transmission of non-standard policy measures relevant for our study. Section 3 describes the data set. Section 4 presents the empirical methodology. Section 5 discusses the pass-through of standard measures and section 6 the pass-through of non-standard measures. Section 7 highlights the macroeconomic implications of our findings. Section 8 concludes.

\section{Channels of unconventional monetary policy transmission}

The literature analysing the mechanics of monetary policy transmission is extensive. Prior to the period we consider, monetary policy in developed countries was conducted primarily by manipulating the short-term interest rate, which is a determinant of consumption and investment decisions. Three transmission channels are typically emphasised: the expectation channel, the interest rate channel, and the credit (bank lending and borrower's balance sheet) channel, see e.g. Bernanke and Gertler (1995), or Mishkin (1996). These channels are well understood and sufficiently agreed upon to require no further discussion. When analysing non-standard policies, a number of additional channels may matter. Here we focus on those which may be most relevant for the credit easing (CE) and quantitative easing (QE) measures.

CE measures were introduced to support private sector credit flows and to counteract weak inflation dynamics in situations where traditional interest rate instruments cannot be used. They alter the size and the composition of the asset side of the central bank balance sheet. QE measures were also conceived to ease private sector borrowing conditions and to counteract deflation risks. Contrary to $\mathrm{CE}$, they involve a pre-defined expansion of the liabilities side of the 
central bank balance sheet and no explicit reference to the assets it holds. While CE and QE measures are different, the channels through which they may affect the economy are similar.

The cost relief channel is the mechanism through which non-standard measures are expected to improve banks' refinancing conditions. This channel is prominent for CE measures, which are designed to reduce banks' marginal cost for targeted lending activities. By allowing banks to replace market funding with central bank funding, the policy directly impacts the supply of bank bonds. By arbitrage, this scarcity of securities should translate into lower yields for all bank bonds, including those issued by intermediaries not participating to the programme. In turn, this should lead to lower lending interest rates to the private sector. QE measures are likely to produce similar effects: if bank bonds are perceived to be close substitutes for the asset purchased by the central bank, increases in the prices of the targeted asset should lead to a fall in bank bond yields (and this should be accompanied by a fall in the lending price.

QE measures are expected to activate a portfolio rebalancing channel. Central bank purchases change the relative supply of marketable assets and their yields, especially if the liquidity the private sector receives is not a perfect substitute for the liquidity contained in the assets sold. Sellers of financial assets may thus rebalance their portfolios by buying assets with characteristics similar to those sold to the central bank. By increasing the price of sovereign bonds, the policies make lending more attractive relative to other investment possibilities, therefore supporting an expansion of bank lending. CE measures could also produce similar adjustments. Since the amount that banks borrow is a multiple of their eligible lending, the extra liquidity can be used to purchase, e.g., government and private sector securities. Moreover, the repayment of maturing bonds by banks participating in the programme may trigger portfolio rebalancing by bond holders. The portfolio rebalancing channel has been found important in the US by Krishnamurthy and Vissing-Jorgensen (2011), in the UK by Joyce et al. (2011) and in the euro area by Altavilla et al. (2015).

Finally, non-standard measures are a way for central banks to signal to market participants the intended path of future policy rates. This signalling channel works through a credible commitment to keep interest rates low: if central banks raise interest rates, they will suffer losses on the assets purchased under the programme (Eggertsson and Woodford, 2003). The commitment mechanism may have two effects: it may trigger a downward revision of expectations for future short-term rates - for CE this happens because of the long period of abundant liquidity implied by the maturity profile of the measures. It may also re-anchor inflation expectations, by providing market participants information about future short-term interest rates. The signalling channel is expected to affect the entire yield curve but the effects depend on the maturity of 
the bonds purchased. The importance of this channel has been studied in Krishnamurthy and Vissing-Jorgensen (2011), Bauer and Rudebusch (2014), and Altavilla et al. (2015).

\section{The data set}

The analysis makes use of two proprietary bank level data sets, regularly updated at the ECB. The first, called Individual Monetary and Financial Institution Interest Rates or IMIR, contains information on individual deposits and lending rates charged by banks for different maturities and for different loan sizes. We construct bank-level composite indicators of borrowing rates of non-financial corporations and of households, weighting lending rates for different maturities and different loan size by new loans volumes. We do the same for deposit rates. Using new volumes at each maturity is important to make sure that the composite indicator correctly reflects the average lending rate applied by each bank. The weighting scheme we employ takes into account the fact that loans may be issued at floating or fixed interest rate. The distinction is not crucial for lending rates to non-financial corporations - the vast majority of loan contracts are agreed at a flexible rate. However, it is relevant for lending rates to households. For example, in Italy, Ireland, Austria, Finland, Portugal the share of fixed rate loans for house purchases is below 25\%; in Belgium, Germany and France, on the other hand, more than $80 \%$ of mortgage agreements have a fixed rate. Similarly, while savings banks tend to prefer loans at fixed rates, commercial banks have a more balanced portfolio of fixed and flexible mortgage loans. Clearly, these differences matter: the higher the share of fixed rate loans is, the slower changes in the policy rate will be transmitted to household lending rates. We checked that the constructed indicators are representative of the banks' portfolios and made sure that no compositional biases resulted from to the fact that some banks lend primarily long term and others short term, or that some lend to small firms (small amounts) and other to large corporations (large amounts).

From another proprietary data set called Individual Balance Sheet Indicators, or IBSI, reporting the main asset and liability items of over 260 banks resident in the euro area from July 2007 to December 2015, we obtain data on the amount of outstanding loans, the exposure to sovereign debt and other relevant bank balance sheet information. We restrict the sample to head institutions and subsidiaries, so that each bank can be treated as independent (legal) entity. This would not have been possible if branches were also included since a head institution must cover branch losses, with consequences for regulatory constraints and risk-taking behaviour.

The two data sets have rich cross-sectional information: we know whether a unit is a head institution or a (domestic or foreign) subsidiary; whether it is a large or a regional/local bank 
and the country where it is located; and there are indicators of its business model (whether it lends more to non-financial corporations or to households, whether it funds itself more through capital or wholesale markets, etc.). The sample is representative of aggregate and of crosssectional patterns: it covers about $75 \%$ of country aggregates and the cross-country distribution reflects the concentration in the area - see table A.1. For comparison, the stress testing exercise conducted by the European Banking Authority in 2014 included about 100 banks and balance sheet characteristics were only irregularly observed.

We match the information present in these data sets with information on bank bond yields (obtained from Markit - Iboxx), on regulatory capital ratios, and on non-performing loans (obtained from the commercial bank data provider SNL Financial) and on CDS (from Datastream). Table 1 has information on the main items of banks' balance sheet.

The average lending rate to non-financial corporations (NFC) for banks belonging to the upper quartile of the distribution is about 130 basis points higher than the average lending rate for banks belonging to the lower quartile. This difference increases to 160 basis points when we consider lending rates to households $(\mathrm{HH})$. A similarly large differential is present in bank bond yields (190 basis points) and in deposit rates (110 basis points). The spread in the distribution of sovereign debt exposure, capital ratios, leverage, non-performing loans, and credit risk is also quite large. We will use these balance sheet variables to group the cross-sectional distribution of monetary policy pass-through we obtain. Notice also that banks in our sample are medium sized, as measured by total assets, but very large banks are also present.

\section{The econometric methodology}

To address the questions of interest we use a cross-sectional Vector Autoregressive (VAR) methodology. In contrast to static pass-through equations, which are typically estimated with single-equation panel techniques, our approach has two main advantages. First, it allows for endogenous interaction between lending and funding conditions within a bank in response to monetary policy changes, an interaction that is neglected with single equation methodologies. Second, it permits dynamic feedbacks between lending and funding conditions. These dynamic repercussions are disregarded in static models and improperly measured in single equation dynamic setups. Furthermore, given the heterogeneities we have highlighted, standard panel data techniques, which assume that the dynamics of the endogenous variables are homogeneous, are inappropriate. The panel VAR model, suggested by Canova and Ciccarelli (2009) is potentially useful in this situation. However, the sparse nature of the dynamic interactions between banks 
makes the setup inefficient. Thus, to analyse the pass-through of monetary policy decisions, we proceed in two steps. In the first we use the time series dimension of the data, bank by bank, to estimate the dynamic response of lending rates (margins) to policy disturbances. In a second step, we sort the distribution of pass-throughs we computed using bank-specific characteristics and measure the average difference between the upper and lower quartiles of the distribution. Since the degree of pass-through might depend on country-specific factors (such as unemployment, sovereign risk, or expectations about economic activity) and on bank-specific characteristics (such as cost of funding, and balance sheet conditions), we condition on country-specific factors when studying the monetary pass-through as a function of bank-specific characteristics.

Two important points about our methodology should be stressed. First, banks do borrow and lend in the overnight market but, over a month, the positions are generally averaged out. Because dynamic interactions across banks are negligible and static interactions are likely to be small, computing the pass-through bank by bank entails little loss of information. Second, our two-step methodology is equivalent to allowing the intercept, the slope and the variance of the empirical model to feature (non-linear) interaction terms with bank-specific characteristics. Sa et al. (2014) used this approach to study the dynamics of UK housing market.

For each bank, the dynamic interactions among the endogenous variables are assumed to follow an unrestricted VAR. The contemporaneous relationships have a block recursive structure. The vector of bank variables $y_{i t}$, is related to country-specific variables $x_{j t}$ and area-wide variables $z_{t}=\left[z_{1 t}, z_{2 t}\right]^{\prime}$, where $z_{1 t}$ is the policy rate, according to:

$$
y_{i t}=A_{i} x_{j t}+B_{i} z_{t}+u_{i t}
$$

In addition, country-specific variables respond to area-wide variables but not vice versa:

$$
\begin{aligned}
x_{j t} & =C_{j} z_{t}+e_{j t} \\
z_{t} & =v_{t}
\end{aligned}
$$

Since the VAR for each bank features different endogenous variables, we constrain $v_{t}$ so that the response of the policy rate to its own shocks is the same in each VAR. This amounts to make the policy rate weakly exogenous with respect to country-specific and bank specific variables.

Each VAR includes three bank-specific variables (the lending rate, the deposit rate, and bond yields, when available) and three country-specific variables (10-year sovereign bond yields, the expected default frequency of non-financial corporations, and the unemployment rate). The 
latter two variables are employed to capture business cycle conditions; the sovereign yield is used because a large portion of bank assets are in the form of local sovereign debt. Benchmark yields on 10-year sovereign debt are from DataStream; the expected default probability of nonfinancial corporations is from Moody's and the unemployment rate is from Eurostat. Other country-specific variables could be included but the chosen variables capture well those events that may affect bank pricing decisions. It is important to include the expected default frequency for each country to control for potential changes in the riskiness of banks' customers which may lead to variations in the distribution of lending rates distinct from those we are care.

To make our results comparable with those present in the literature and to facilitate the interpretation of the results, we let $z_{t}$ include only the EONIA rate, which we use as a policy instrument. Adding other area-wide variables, such as the inflation rate or the unemployment rate, to the $z_{t}$ vector will refine the informational content of EONIA surprises but does not change the main features of the results. The choice of EONIA as the policy rate requires a few words of explanation. The three main ECB policy rates - the rate on the marginal lending facility, the rate on the main refinancing operations (MRO), and the rate on the deposit facility (DF) - are available but move discontinuously with discrete jumps when the Governing Council decides rate changes. By contrast, the EONIA rate evolves daily, closely tracks the MRO rate in periods of normal liquidity and the DF rate when liquidity is abundant, and does not have a floor at zero. Hence, the EONIA rate is a good indicator of the degree of monetary accommodation the ECB tries to achieve, both in normal and abnormal times.

As mentioned, slope heterogeneities prevents us from jointly using the time series and the cross-sectional dimensions for estimation. In addition, we can not rely on standard classical asymptotic theory for inference since the time series dimension of the panel is moderate. To derive the exact small sample distribution of the quantities of interest we employ Bayesian methods. Let $\beta_{i}$ be the vector of bank-specific coefficients, $\beta=\left[\beta_{1}^{\prime}, \ldots \beta_{N}^{\prime}\right]$, let $\Sigma_{u}=\operatorname{diag}\left[\Sigma_{u, 1}, \ldots \Sigma_{u, N}\right]$ be the covariance matrix of the disturbances, and let $\theta=(\beta, \Sigma)$. We use a Normal-Inverse Wishart prior for $\theta$, modified to incorporate i) a Minnesota prior, so that the empirical model for each unit is shrunk toward a vector of random walks with drifts; ii) a "sum-of-coefficients" prior, which restricts the sum of the AR coefficients of each equation, see Doan, Litterman, and Sims (1984), and iii) a "dummy-initial-observation" prior, which accounts for potential non-stationarities in the data, see Sims and Zha (1998). The vector of hyper-parameters controlling the informativeness of the prior, $\zeta$, is treated as random, to account for the uncertainty surrounding the specification of the prior, and the posterior of $(\theta, \zeta)$ is jointly computed.

Denote by $\beta_{i}^{m}$ a draw from the marginal posterior of $\beta_{i}$. An estimate of the responses of 
bank variables to a conventional monetary policy disturbance is:

$$
y_{i t}^{m} \equiv \omega_{i}^{m}(L) v_{t} i=1,2, \ldots N
$$

where $\omega_{i}(L)$ is a $3 \times 1$ vector for each $\mathrm{i}$, and $\mathrm{L}$ denotes the lag operator. Letting $y_{i t}^{1, m}$ be the response of the lending rate at time $t$ for bank $i$, the pass-through at horizon $h$ is:

$$
P T_{i}^{h, m} \equiv \frac{\sum_{\iota=0}^{h} \omega_{i \iota}^{1, m}}{\sum_{\iota=0}^{h} \delta_{\iota}^{m}}, h=1,2, \ldots H
$$

where $\mathrm{z}_{1 t}=\delta(L) v_{t}$. Similarly, letting $w_{i t}^{1, m}=y_{i t}^{1, m}-y_{i t}^{2, m}=\psi^{i m}(L) v_{t}$, where $y_{i t}^{2, m}$ is the response of the deposit rate, the pass-through to lending margins uses $\psi_{i i}^{1, m}$ for $\omega_{i \iota}^{1, m}$ in (5). The distribution of pass-throughs for each $\mathrm{h}$ is obtained exploiting cross-sectional and individual bank parameter variations. If lending rates responses were homogenous, i.e. $\omega_{i}^{m}=\omega^{m} \forall i$, crosssectionally averaging (5) gives the pass-through obtained pooling cross-sectional information. This quantity, however, would be different from the one computed in single pass-through equations, because the contemporaneous and lagged feedbacks from deposit rates and bank bond yields to lending rates and the dynamics of country specific variables are disregarded. When we analyse standard measures, we use data from July 2007 to April 2014. The pass-through of non-standard measures is obtained using the parameter estimates for this sample and a path for certain endogenous variables from May 2014 to December 2015, as described in section 6 .

Although the sample includes 260 banks, the actual number of banks we employ is smaller. This is because bank bond yields are available only for a subset of (mostly large) banks, and some balance sheet characteristics might either be available for a limited number of banks (see Table 1) or simply not available for at least of 40 consecutive months - a required selection criteria for a bank to be included in our sample, to ensure that we have a sufficient number of time periods to analyse. In the baseline exercise, we eliminate bank bond yields from the VAR and consider a larger sample of banks $(N=168)$. We also consider the smaller sample of banks for which bank bond yields are available $(N=76)$. As we discuss later, the main conclusions we obtain hold in both samples.

\section{The pass-through of conventional measures}

The stylised evidence discussed in the introduction suggests that lending rates of banks located in financially stressed and non-stressed countries behave differently. For example, the median 
of the distribution of lending rates comoves less with policy rate changes in the stressed than in non-stressed countries in the 2011-2014 period. To examine whether this is still true when we condition on a number of factors, we compute lending rate responses to policy surprises and sort the distribution of pass-through by type of countries. Panel A of Figure 2 shows the distribution of lending rate responses and of the pass-through for all banks (first column), for banks operating in stressed countries (second column) and in non-stressed countries (third column). Responses are constructed assuming a persistent 100 basis point decline in the policy rate.

The median instantaneous pass-through is 0.25 and the median medium run pass-through is about 0.6, much lower than what was estimated prior to 2007 (Hristov, et al. 2014). Thus, the interest rate channel of monetary policy has considerably weakened. The distribution of pass-through is very dispersed: after 24 months, the highest posterior 68 percent interval goes from about 0.3 to 1.0. However, the location of banks does not explain this dispersion: the median of the distribution of pass-through has similar evolution and magnitude in both types of countries, and the highest posterior 68 percent intervals overlap. How, then, does one reconcile Figure 2 and Figure 1? There are two reasons why the patterns differ. The evidence in Figure 1 is unconditional while Figure 2 is constructed conditional on a monetary policy shock. There could be other country-specific disturbances driving the dynamics of lending rates; financial and technological shocks are few candidates that come to mind. Country-specific factors are considered in Figure 2 but not in Figure 1. Thus, the two figures are consistent if, e.g., different probabilities of default are responsible for different lending rates across countries.

A concern when analysing the impact of policy surprises is that results might be affected by the presence of non-standard policy measures. For example, since October 2008, the ECB has been lending liquidity to banks through fixed-rate full-allotment auctions. Since the EONIA rate adjusted accordingly, its innovations reflected both standard and non-standard monetary policy measures (see Ciccarelli et al, 2016). To show that the presence of non-standard provisions in the sample is inconsequential for the results, we matched the data with confidential information about the participation of banks in the two 3-year Very Long-term Refinancing Operations (VLTROs) conducted on the 20th of December 2011 and the 28th of February 2012 ${ }^{1}$ and checked whether banks bidding in the operations (regardless of the amount actually taken up) displayed different pass-throughs than banks not participating the program. About half of the banks in our sample bid in one of the two operations, making the comparison statistically relevant. Panel $\mathrm{B}$ of Figure 2 shows that lending rate responses and the pass-through are similar in the two

\footnotetext{
${ }^{1}$ The first VLTRO provided $€ 489$ billion to 523 banks, the second allotted $€ 530$ billion to 800 banks. The net increase in liquidity provision was around EUR 500 billion.
} 
groups of banks.

Figure 3 reports the mean value of the monetary pass-through in the upper and lower quartiles of the distribution and the 75 and 95 percent posterior intervals for the difference. We group the distribution according to: (i) the exposure to domestic sovereign bonds, (ii) the (Tier 1) capital ratio, (iii) the degree of stability of the funding structure, as defined by Basel III, and (iv) the share of non-performing loans as a percentage of risk-weighted assets. To insure that the sorting variable is predetermined, we use bank characteristics recorded on July 2007.

Three features stand out. First, the pass-through is low for banks heavily exposed to domestic sovereign debt and with a weak capital position. For example, a persistent 100 basis point decline in the EONIA rate generates a medium run pass-through of about 110 basis points for highly capitalised banks, and of about 70 basis points for less well capitalised banks, and of over 120 basis points for the less exposed banks and of about 80 basis points for heavily exposed banks. The fact that banks with a strong capital position and low sovereign bond exposure have a long-run pass-through greater than one may indicate that they strategically take advantage of their balance sheet position to expand their loan market share (see e.g. Gilchrist et al., 2015, for a model with such features). Our finding that exposure to sovereign debt matters is consistent with the evidence in Drechsler et al. (2014), Altavilla et al. (2016) and Peydró et al. (2016) about risk-shifting incentives during crisis times. Note that the maximum difference in average pass-through sorted by these two features is up to 40 basis points. Because the instantaneous pass-through is roughly similar, differences across quartiles are due to the fact that poorly capitalised and highly exposed banks adjust their rates sluggishly over time. Van den Heuvel (2003) describes a model where lending rates of banks with weak capital position are sluggish because policy rate changes affect bank capital. Our results suggest that the effect on bank capital may be delayed, e.g., capital requirement may bind only on the dynamic adjustment path, but may be long lasting. The second outstanding feature is that quartile differences in pass-through sorted by the stable funding variable are small and temporary. Finally, note that quartile differences in pass-through sorted by non-performing loans are insignificant.

When the smaller sample of banks is considered, results are qualitatively similar when sovereign exposure and capital ratios are used to sort the distribution of pass-through (see Figure 4). Quantitatively, quartile differences in pass-through sorted by sovereign debt exposure are larger - the maximum difference is about 50 basis points. The stability of the funding structure is now irrelevant; the share of performing loans has some temporary, differential effect and banks with a high percentage of non-performing loans are slower in adjusting their lending rates for up to 8 months. Recall that this alternative sample includes primarily large banks - these are the 
banks issuing bonds to fund their operations. Hence, the share of non-performing loans is an important factor in explaining lending rate differences for large banks; stable funding differences matter primarily for small banks.

In sum, the median monetary pass-through declined considerably between 2007 and 2014 . The decline is common to both stressed and non-stressed countries and consistent with the idea that frictions in pricing loans became, in general, more binding (see Gerali et al., 2010). Frictions interact with certain bank characteristics, in particular capital ratios and exposure to sovereign risk. This interaction seems responsible for both the disconnect between the dynamics of the policy rate and of the distribution of lending rates, and the large spread in the distribution of lending rates observed up to 2014. Banks became more prudent, charging customers at rates higher than one would have expected from the dynamics of the policy rate, because the deterioration of the asset side of their balance sheet and difficulties in securing appropriate funding threatened their long-run viability.

\section{The pass-through of non-standard measures}

In this section we evaluate whether the $\mathrm{CE}$ package - the targeted longer-term refinancing operations (TLTROs) announced in June 2014 - and the QE package - the asset purchase programme (APP) announced in January 2015 - helped to change the dynamics of the distribution of lending rates and to reduce its dispersion. We also aim to identify the characteristics of the banks most affected by central bank non-standard actions.

Although the EONIA rate responds to liquidity changes induced by the CE package, the VARs have no variable capturing central bank balance sheet expansion. To study the effects of non-standard measures we thusproceed in two steps. We calculate the responses of certain variables to announcements of non-standard measures from May 2014 to December 2015 using a high-frequency event-study methodology (see e.g. Krishnamurthy and Vissing-Jorgensen 2011; Altavilla et al. 2015). Then, we compare lending rates dynamics obtained mapping the policyinduced component of these variables onto individual bank lending rates with those obtained assuming that these variables evolved unconditionally since May 2014. We exploit the fact that $\mathrm{CE}$ and $\mathrm{QE}$ programmes alter the expected path of the EONIA rate - this is the signalling channel of section 2 - and affect sovereign bond yields and banks credit risk, as reflected in the market price of bank debt - these reflect the portfolio rebalancing and cost relief channels.

This two-step approach is appealing because it captures the instantaneous financial markets effects of non-standard measures, which are likely to be washed out with monthly data (see e.g. 
Altavilla et al. 2016; Bluwstein and Canova, 2016; Ghysels et al., 2015). While non-standard measures may have been taken, in part, in response to failure of the lending rate distribution to adjust to policy rate changes, the methodology we employ is valid since, at the daily frequency, announcement dates are predetermined relative to the distribution of lending rates.

\subsection{The impact of non-standard policies on financial markets}

Quantifying the impact of non-standard measures on financial variables is challenging because many concurrent events affected the EONIA rate and sovereign and bank bond prices in 2014 and 2015; expectations of US monetary policy tightening and oil price declines are two such events that come to mind. We use a narrative approach to identify policy surprises and run an auxiliary regression to obtain the path of the EONIA rate, of sovereign and of bank bond yields that would have occurred if the euro area had been hit only by non-standard policy announcements. The regression we run is

$$
\Delta y_{t}=a D_{t}+b D_{t-1}+c X_{t}+e_{t}
$$

where $\mathrm{D}_{t}$ is a vector of dummy dates and $\mathrm{X}_{t}$ a vector of macroeconomic surprises in the euro area and the US and $\mathrm{e}_{t}$ iid disturbance. $\mathrm{D}_{t}$ includes twenty-eight announcement dates: for CE measures we include the Governing Council meeting dates held in May and June 2014; for QE measures we follow Altavilla et al. (2015) and use official communications or hints about the likely implementation of the programme. The policy decision (made public on 3 December 2015) to extend the QE programme up to March 2017, to reinvest the principal payments, and to enlarge the set of eligible assets to regional and local government debt may have created anticipatory effects. We take these into account by including the three Governing Council meeting dates since September 2015 and six dates associated with ECB's official speeches and data releases that led financial markets to revise their expectations about the likelihood of additional measures $^{2}$. We do not consider anticipatory effects of the 3 March 32016 announcement of the new targeted longer-term refinancing operations programme (TLTRO-II), of the increase in the monthly purchases of the APP programme (from $€ 60$ to $€ 80$ billion) and of the enlargement of the list of eligible assets, because there were no hints that these measures were going to be

\footnotetext{
${ }^{2}$ The six events are Mr Draghi's intervention in New York on 4 December 2015, which had clarified the easing potential of the December package; the speeches Mr Praet's speeches on 22 September and 27 October 2015; the Bloomberg interview by Mr Constancio on the 25 November 2015; the market commentaries associated with the better-than-expected Economic Sentiment Indicator release on 29 October 2015; and the Reuters news regarding the growing consensus across Governing Council members on further deposit rate cuts on 9 November 2015.
} 
implemented by December 2015. $X_{t}$ is computed as the standardised difference between the actual value of the data released and the consensus forecast made by professional forecasters as collected by Bloomberg. The dependent variable $\Delta y_{t}$ measures the daily change in either the EONIA rate, or bank bond or sovereign bond yields. In (6) we use a two-day announcement window to allow for a sluggish market reaction to the news, which could have been possible given the novelty of the programmes. The results with a one-day window are similar. The policy component of the changes in the three variables is retrieved cumulating, monthly, the predicted path over the projection sample.

Figure 5 reports the median effect (solid blue line) and either the cross-country or cross-bank variations (red dashed lines). The path for the EONIA rate is the same for all banks; the path of sovereign yields is country-specific, and the path of bank bond yields is bank-specific. Banks located in stressed countries benefited most from the announcements. By December 2015, their funding costs fell by 50 basis points and the sovereign bond rates fell by 100 basis points in the median. By comparison, a typical bank in non-stressed country saw funding cost and sovereign bond yields reductions of 30 and 60 basis points, respectively, in the median.

\subsection{From financial variables to lending rates}

To measure the effects non-standard measures have on lending rates, we forecast them from May 2014 through December 2015, i) conditional on the path of the EONIA rate, of sovereign and of bank bond yields that would have occurred if the euro area were hit only by non-standard policy announcements, and ii) unconditionally. Formally, we compute:

$$
u_{i t+h}=E\left(y_{i t+h}^{1} \mid \Omega_{t}, z_{1 t+h}^{*}, y_{j t+h}^{*}\right)-E\left(y_{i t+h}^{1} \mid \Omega_{t}, z_{1 t+h}, y_{i t+h}\right)
$$

where $\Omega_{t}$ is the state of the economy at time $t, y_{i t+h}^{1}$ is the path of the lending rate of bank $i$ at horizon $h=1,2, \ldots, z_{1 t+h}^{*}$ and $y_{i t+h}^{*}$ are the policy-induced paths and $z_{1 t+h}, y_{i t+h}$ the unconditional paths for the three relevant variables. $u_{i t+h}$ measures the response of lending rate of bank i to non-standard policy surprises (see Canova, 2007). The cross-sectional distribution of $u_{i t+h}$ and for the implicit pass-through are in Figure 6.

Non-standard measures significantly lowered lending rates - the median reduction is about 40 basis points - and the reduction is larger for banks operating in stressed countries (50 vs. 30 basis points). The implicit pass-through is also large: it is close to one in the median for stressed countries and about 0.8 for non-stressed countries by December 2015. Thus, the funding cost relief that banks enjoyed following were transferred to borrowers more in countries where 
the monetary accommodation would have been most welcome. One may wonder whether the analysis is appropriate for banks located in, say, Greece or Cyprus, given that they were unable to obtain liquidity from the Central bank. While market segmentation is a concern in theory, it is irrelevant in our exercises because Greek and Cypriot banks are not in either of our samples - data on their non-performing loans is not available.

Balance sheet characteristics matter when it comes to explaining the reduction in the spread of the distribution of lending rate responses (see Figures 7 and 8). Non-standard measures were particularly effective in lowering lending rates for banks with a high share of non-performing loans and low capital. The median difference between the upper and lower quartiles of the distribution sorted by these characteristics is up to 40 basis points and differences become strongly significant after about 18 months. Differences between the upper and lower quartiles of the distribution sorted by stable funding are insignificant. Some significant difference occurs when sovereign exposure is used as a sorting device, but the effect is temporary and significant only in the sample of large banks.

\subsection{A few additional exercises}

The analysis so far has been concerned with lending rates to non-financial corporations. Since we also have information about lending rates to households, we repeat the pass-through exercises with this variable and two goals in mind: we want to see whether the effects of non-standard measures are robust; we are curious as to whether banks strategically used funding costs reliefs in the two markets to acquire market shares. Figures A.1-A.4 in Appendix A presents the passthrough distribution by type of country and by bank characteristics following conventional and non-standard policy surprises Qualitatively speaking, all the conclusions we obtained also hold for lending rates to households. In particular, in response to conventional policy changes the median pass-through is low (about 0.5) and the cross-sectional distribution is wide; the location of the bank does not explain the dispersion of the distribution of pass-throughs but the capital ratio and the exposure to sovereign risk do. Non-standard measures increased the median pass-through; they were more effective on the household lending rates in stressed countries, and affected most banks with a high share of non-performing loans and with low capital. Quantitatively speaking, the cross-sectional dispersion of pass-throughs in response to both standard and non-standard measures is smaller than for lending rates to firms and the effects of non-standard measures is also smaller.

It is of interest to evaluate whether bank credit risk is important in explaining the pattern 
of lending rate responses to non-standard measures. It is well know that non-standard measures may also work through the so-called confidence channel (see e.g., Bluwstein and Canova, 2016). Here we want to evaluate whether banks with high perceived credit risk behaved differently than banks with low perceived risk. The first row of Figure A6 in Appendix A shows that, in agreement with work by Acharya et al. (2015), banks that financial markets perceived to be more risky (as measured by individual banks CDS) were those whose lending rates to financial corporations fell most in response to the non-standard measures. The difference with banks with low CDS was about 20 basis points, 18 months after the beginning of the programmes.

An additional piece of evidence supporting the idea that non-standard measures helped comes from the lending rates of banks participating in at least one TLTRO operation. While part of the decline in lending rates offered by these banks is due to the fact that borrowers scaled back their recourse to wholesale funding, the second row of Figure A6 suggests that these banks lowered their rates substantially more than their non-participating peers. Interestingly, with lending rates to households this is no longer true: bidders and non-bidders display similar lending behaviour (see the last two rows of figure A6). This accords with intuition since mortgages were excluded from the CE programme.

\subsection{Side effects? Pass-through to lending margins}

There are several reasons to be concerned with the dynamics of lending margins - defined as the difference between the lending rate to non-financial corporations and the deposit rate - in responses to non-standard measures. Several studies (e.g. Gambacorta, 2008; and Alessandri and Nelson, 2015) noticed that in the presence of frictions in pricing loans and deposits, changes in monetary policy may affect the returns from maturity transformation activities and thus alter banks' profitability. In theory, the impact of non-standard measures on bank profitability is ambiguous. QE policies have two contrasting effects: on the one hand, they flatten the yield curve, make maturity transformation less attractive, and thus hamper banks' profitability. On the other hand, they may improve the capacity of borrowers to honour their commitments, increase the quality of the assets held in banks' portfolio, and lead to a decline in provisioning needs. Asset price increases also have a beneficial impact on bank equity through valuation gains. In addition, as suggested by Drechsler et. al (2016), when the banking sector is imperfectly competitive, changes in monetary policy alter banks' effective market power. Thus, when financial frictions matter, monetary policy influences not only how much the banking system lends, but also how it is funded, the quantity of safe and liquid assets it produces, and its riskiness. 
The dynamics of lending margins also matter from a different perspective. The magnitude of the pass-through is typically used to gauge the effectiveness of the interest rate channel of monetary policy. However, the dynamics of deposit rates are equally important since they affect the incentives of households to save. When the pass-through is imperfect, but deposit rates responses track lending rates responses, monetary policy may be as effective as when the monetary pass-through is complete, but banks manipulate deposit rates to alter lending margins.

While an examination of the impact of monetary policy changes on banks profitability is beyond the scope of this paper, the dynamic responses of lending margins may give us some hints about the relevance of these concerns.

Non-standard surprises are associated with a substantial and statistically significant compression of lending margins - about 20 basis points by December 2015 in the median (see Figure 9). The reduction is more pronounced for banks operating in stressed countries (30 vs. 15 basis points in the median), even though the cross-sectional variations in each group is large. Banks with a low level of capital, with higher exposure to sovereign debt, and a higher share of non-performing loans have experienced a larger decline of their lending margins (see Figure 10). Thus, non-standard measures generate an important trade-off: mending the transmission channel of monetary policy and reducing borrowers' costs compresses lending margins of certain classes of banks. This trade-off makes it important to consider the macroprudential consequences of non-standard measures, at least in the short run.

\section{Macroeconomic implications}

The monetary pass-through was quite imperfect for a large portion of our sample. Under working capital constraints, this imperfection has implications for the evolution of the distribution of marginal costs that firms face. With a standard specifications of firms pricing decision, homogeneous preferences and conventional technologies for producing monopolistically competitive goods, the distribution of marginal costs in turns imply through a cost channel (see e.g. Ravenna and Walsh, 2008), a distribution of good specific inflation rates.

To measure the effects that the low pass-through obtained in the pre-2014 period had on inflation, we conduct a simple exercise using a standard New Keynesian model with sticky prices, habit persistence, and working capital described in appendix B, calibrating the parameters to match important features of the Euro area. We calculate the differences in the inflation rate produced by the model with i) the actual paths of EONIA and of the median of the distribution of lending rates for the 2009-2014 period and ii) the actual path of the EONIA and a counterfactual 
path for the lending rate, equal to the path of the EONIA rate plus a steady state spread. On average, the inflation rate should have been 52 basis points higher with the pass-through observed in the data. Core CPI average inflation rate in these five years in the euro area was roughly 1.0 percent. Thus, actual inflation rates were much lower than the reference value (2.0 percent) and the rate expected by the model. Three reasons may account for this outcome. First, in the period we analyze the slope of the Phillips curve has considerably flattened. Second, as Gilchrist et al. (2015) have suggested, firms may trade-off price and market share variations when they face financial frictions. In particular, firms with lower marginal costs may slash prices more than expected by a standard Phillips curve to acquire market shares and thus increase revenues and profits. If the goods produced by these firms are dominant in core CPI inflation, the average behavior of inflation for the 2009-2014 period could be explained. Third, the inflation effects of sticky lending rate dynamics were swamped by the contractionary effects other shocks (e.g., financial shocks) had on aggregate demand.

To measure the effects that non-standard policies had on the output gap and inflation, we compare two scenarios. In the first, the policy rate, the lending rate, and the deposit rates reproduce the paths the EONIA rate and the median values of the lending rate and the deposit rate distribution followed in the period $2014 \mathrm{q} 2-2015 \mathrm{q} 4$ in response to the policy announcements. In the second, the three rates are held constant at their 2014q1 values. In other words, we compute the difference made by non-standard policies relative to the no-policy-change situation. Figure 11 reports the paths for the output gap and inflation under the two policies. Non-standard policies had a positive and significant effect on inflation: the maximum impact is two quarters after the beginning of the programme and by 2015q4 the difference with the no-policy scenario stabilises at around 0.6 percent. They also had a positive effect on the output gap: by $2015 q 4$ the output gap would have been lower by about 0.5 percent in the no-policy scenario. The mechanism inducing these changes is simple: non-standard policies, by decreasing the lending rate, decrease marginal costs for firms (borrowing costs are lower) and this expands the aggregate supply, with positive effects on employment. On the other hand, the fall in the deposit rate, increases the incentives of consumers to spend. With the parameterisation we employ, the aggregate demand effect is large and drives inflation up and the output gap down.

Finally, we examine what would have happened to the output gap and inflation if nonstandard measures were perfectly passed-through to lending and deposit rates. We construct a scenario where the lending and deposit rates perfectly comove with the policy rate and differ by average spreads observed prior to 2007 , and compare it with the policy scenario constructed in Figure 11. Figure 12 presents the paths of the output gap and inflation under imperfect 
and perfect pass-through. Inflation would increase more in the short run under perfect passthrough, but by $2015 q 4$ the effect would be similar. The path for the output gap in the two scenarios is statistically insignificant. These results agree with Figure 6: the pass-through for the 2014q2-2015q4 period was already quite high.

A few important caveats need to mentioned. First, since the model features a representative agent, the redistributive effects that non-standard policies have on borrowers and lenders are not captured in our calculations. Second, the model is highly stylised and since banks' pricing decisions are not explicitly modelled, the effects of having a more stable and less risky banking system, which could be a by-product of non-standard policies, are disregarded in our exercises. Third, the model does not feature any financial frictions on the consumer or the producer side. Since non-standard policies may have reduced these frictions, we are unable to evaluate the consequences they may have on the relationship between banks, producers and consumers. Thus, the numbers we report represent the lower bound for the output gap and inflation effects that non-standard policies may have had in the euro area.

\section{Conclusions}

This paper investigated the reasons why the interest rate channel of monetary policy in the euro area had weakened considerably over the last 10 years and studied how non-standard measures may have helped to mend the link between monetary policy and real activity. The analysis makes use of a novel and large data set covering European banks and employs information about their balance sheet characteristics and their funding structure. We exploit the time series dimension of the data, bank by bank, to construct the cross-sectional distribution of pass-throughs, use balance sheet characteristics to sort them, and measure the average difference between the top and bottom quartiles of the distribution.

When considering standard policy rate surprises, we find a significant fall in the median pass-through relative to the pre-2007 period. Balance sheet characteristics, in particular the capital position and the exposure to sovereign risk, explain the dispersion in the cross-sectional distribution of pass-throughs. The location of a bank, however, does not. Following a monetary expansion, poorly capitalised and highly exposed banks reduced their lending rates less than other banks because the deterioration of the asset side of their balance sheet and the difficulties in securing funding threatened their long run viability.

To evaluate the contribution of non-standard measures to the normalisation of lending market conditions, we isolate the impact these measures have on financial variables via an event- 
study methodology. We then compare the lending rate dynamics obtained by mapping the policy-induced component of the EONIA rate, of sovereign yields and of bank bond yields onto individual bank lending rates, with those obtained assuming that these variables evolved unconditionally since May 2014. The response of lending rates to non-standard measures was strong, the cross-sectional dispersion of responses was smaller than in previous years, and a larger passthrough was achieved. Conditions improved because of funding costs reliefs, dynamic portfolio rebalancing, and signalling effects. Banks with a high level of non-performing loans and low capital were the most responsive to the measures. Large and small banks responded similarly to the measures and lending rates to both non-financial corporations and to households were equally affected. Non-standard measures also produced a significant compression of lending margins. Banks with a low level of capital, greater exposure to sovereign bonds and a high level of non-performing loans experienced the largest decline.

We quantify the macroeconomic impact of non-standard measures. We find that, by December 2015 and absent non-standard measures, inflation would have been 0.6 percent lower and the output gap 0.5 percent higher than actually recorded and that, if the pass-through was perfect, the dynamics of the output gap and inflation would have been insignificantly different.

There are many important issues we did not address in the paper for reasons of space. For example, whether the quality of loans improved after the implementation of non-standard measures, whether small firms benefitted from the improved lending conditions as much as large ones, and whether the maturity of the loans matters for the pass-through. In general, investigating the effects of non-standard measures on the quantity and quality of loans would complement the pricing analysis of this paper. As mentioned, a study of the effects of monetary policy on bank profitability is relevant from a macroprudential point of view, both for standard measures and for those non-standard measures which are becoming the norm in the developed world. An investigation of the bank external finance premium, defined as the difference between the cost of issuing bonds and the cost of financing the operations in the interbank market, could also be very useful to understand whether models of the financial accelerator apply to banks facing collateral constraints. Such an analysis could provide a further link between this paper and the literature studying financial constraints in macroeconomic models. The dynamics of lending rates may be driven by numerous shocks. Characterising whether lending rates are pro or countercyclical in response to these shocks may help us to select among various specifications of financial frictions proposed in the literature. We leave these issues for future research. 


\section{Acknowledgements}

We would like to thank Viral Acharya, Fernando Alvarez, Giacomo Carboni, Mihnea Constantinescu, Domenico Giannone, Gabriel Perez-Quiros, Omar Rachedi, Silvia Miranda-Agrippino, Costanza Rodriguez D'Acri, Luca Sala, Ad van Riet and the participants of the Conferences: Credit dynamics and the macroeconomy, London; the 2nd Oxford-NY Fed Monetary Economics Conference, Oxford; Unconventional Monetary Policy: Effectiveness and Risks, Rome; the CAMP workshop on Commodity prices and monetary policy and of seminars at European Central Bank, Federal Reserve Board, Bank of Spain, Central Bank of Slovakia, Universidad de Murcia, Central Bank of Lithuania, Central Bank of Argentina, Central Bank of Chile, Central Bank of Israel, Central Bank of Belgium for comments and suggestions. Canova's portion of the research was financed, in part, by the Spanish Ministry of Economy and Competitiveness, Grant ECO2015-68136-P and FEDER, UE. The views expressed in the paper are solely ours and do not necessarily reflect those of the European Central Bank or the Eurosystem. 


\section{References}

[1] Acharya V. V., T. Eisert, C. Eufinger, and C. Hirsch (2016) Whatever it takes: The Real Effects of Unconventional Monetary Policy", NYU manuscript.

[2] Acharya V. V., B. Imbierowicz, S. Steffen and D. Teichmann (2015). Does the Lack of Financial Stability Impair the Transmission of Monetary Policy?, NYU manuscript.

[3] Acharya, V. and S. Steffen (2015). The Greatest Carry Trade Ever? Understanding Eurozone Bank Risks, Journal of Financial Economics, 115, 215-236.

[4] Alessandri P. and B. Nelson, (2015). Simple Banking: Profitability and the Yield Curve, Journal of Money, Credit and Banking, 47(1), 143-175.

[5] Altavilla C., Carboni G. and R. Motto (2015). Asset Purchase Programmes and Financial Markets: lessons from the Euro Area, European Central Bank working paper 1864.

[6] Altavilla, C, Giannone D., and M. Lenza (2016). The financial and macroeconomic effects of OMT announcements, International Journal of Central Banking, 12, 29-57

[7] Altavilla C., Pagano M., and S. Simonelli (2016). Bank Exposures and Sovereign Stress Transmission, CEPR Discussion Paper 11269.

[8] Bauer M. D. and G. D. Rudebusch, 2014. The Signaling Channel for Federal Reserve Bond Purchases, International Journal of Central Banking, 10(3), 233-289.

[9] Bernanke B., and M. Gertler (1995). Inside the black box: The credit channel of monetary policy transmission. The Journal of Economic Perspectives, 9, 27-48.

[10] Bluwstein, K. and F. Canova (2016). Beggar-thy-neighbour? The international effects of ECB unconventional monetary policy, International Journal of Central Banking, 12, 69-120.

[11] Canova, F. (2007) Methods for applied macroeconomic research, Princeton University Press, Princeton, NJ.

[12] Canova, F. and M. Ciccarelli (2009). Estimating multi-country VAR models, International Economic Review, 50(3), 929-961.

[13] Ciccarelli, M., A. Maddaloni, and J. L. Peydró (2013). Heterogeneous transmission mechanism: monetary policy and financial fragility in the eurozone. Economic Policy, 28, 459-512.

[14] Ciccarelli, M. A. Maddaloni, and J.L. Peydró (2016). Trusting the bankers: a new look at the credit channel of monetary policy transmission. Review of Economic Dynamics, 18, 979-1002. 
[15] De Santis, R. and P. Surico (2013). Bank lending and monetary transmission in the euro area. Economic Policy, 28, 423-457.

[16] Doan, T., Litterman, R. and C. Sims (1984). Forecasting and Conditional Projections using realistic Prior Distributions, Econometrics Reviews, 3, 1-100.

[17] Drechsler I., Drechsel T., D. Marques-Ibanez, and P. Schnabl (2014). Who Borrows from the Lender of Last Resort?, Journal of Finance, forthcoming

[18] Drechsler, I., A. Savov, and P. Schnabl, (2016). The deposit channel of monetary policy, NBER working paper 22152.

[19] Eggertsson, G. and M. Woodford (2003). The zero bound on interest rates and optimal monetary policy. Brookings papers on economic activity, 1, 139-233.

[20] Gambacorta L. (2008). How do banks set interest rates? European Economic Review, 52, 792-819.

[21] Gambacorta L. and P. E. Mistrulli (2014). Bank Heterogeneity and Interest Rate Setting: What Lessons Have We Learned since Lehman Brothers? Journal of Money, Credit and Banking, 46, 753-778.

[22] Gerali, A., Neri, S., Sessa, L., and F. M. Signoretti (2010). Credit and banking in a DSGE model of the Euro Area. Journal of Money Credit and Banking, 42, 107-141.

[23] Gilchrist, S., Schoenle, R., Sim, J. and E. Zakrajsek (2015). Inflation dynamics during the financial crisis, Boston University, manuscript.

[24] Ghysels, E., Idier, J., Manganelli, S. and O. Vergote (2015). A High Frequency Assessment of the ECB Securities Markets Programme, forthcoming, Journal of the European Economic Association.

[25] Hristov, K., Hulsewig, O. and T. Wollmerhouser (2014). Interest rate pass-through in the Euro area during the Global Financial Crisis. Journal of Banking and Finance, 48, 104-119.

[26] Holton S. and C. Rodriguez d'Acri (2015) Jagged cliffs and stumbling blocks: interest rate pass-through fragmentation during the Euro area crisis, ECB WP1850.

[27] Illes A., Lombardi M. and P. Mizen (2015). Why did bank lending rates diverge from policy rates after the financial crisis?, BIS Working Papers 486, Bank for International Settlements.

[28] Joyce M, A Lasaosa, M Tong and I Stevens (2011). The financial market impact of quantitative easing in the United Kingdom, International Journal of Central Banking, 7(3), $113-61$ 
[29] Kashyap, A. and J.C. Stein, (1995). The impact of monetary policy on bank balance sheets. Carnegie Rochester Conference Series on Public Policy, 42, 151-195.

[30] Kashyap, A., and J.C. Stein, (2000). What do a million observations on banks say about the transmission of monetary policy. American Economic Review, 90 (3), 407-428.

[31] Kishan R. and T. Opiela (2000). Bank size, bank capital, and the bank lending channel. Journal of Money, Credit and Banking, 32, 121-141.

[32] Krishnamurthy, A. and Vissing-Jorgensen, A. (2011). The effects of quantitative easing on interest rates: channels and implications for policy. Brookings Papers on Economic Activity, $43(2), 215-287$.

[33] Mishkin, F. (1996). The channels of monetary transmission: Lessons for monetary policy. NBER working paper no. 5464 .

[34] Peek, J. \& Rosengren, E.S. (1995). Bank Lending and the Transmission of Monetary Policy, in Peek J. and Rosengren E.S. (eds.), Is Bank Lending Important for the Transmission of Monetary Policy?, Federal Reserve Bank of Boston Conference Series, 39, 47-68.

[35] Peydró J.L., A. Polo, and E. Sette (2016) Monetary Policy at Work: Security and Credit Application Registers Evidence, UPF manuscript.

[36] Ravenna, F. and C. Walsh (2008). Optimal monetary policy with the cost channel, Journal of Monetary Economics, 53(2), 199-216.

[37] Sa, F., P. Towbin and T. Wieladek (2014) Capital inflows, financial structure and housing booms, Journal of the European Economic Association, 12(2), 522-546.

[38] Sims, C. and T. Zha (1998). Bayesian methods for multivariate models, International Economic Review, 39, 949-968.

[39] Stein J.C. (1998), An Adverse-Selection Model of Bank Asset and Liability Management with Implications for the Transmission of Monetary Policy, RAND Journal of Economics, $29(3), 466-486$.

[40] van den Heuvel, S. (2002). Does bank capital matter for monetary transmission? Federal Reserve Bank of New York Economic Policy Review, May, 259-263.

[41] von Borstel J., Eickmeier, S. and L.Krippner (2015). The interest rate pass-through in the euro area during the sovereign debt crisis, Bundesbank manuscript. 
Table 1: Descriptive statistics

\begin{tabular}{lccccc}
\hline & N. obs & N. banks & \multicolumn{3}{c}{ Percentile } \\
\cline { 5 - 6 } & & & 25th & 50 th & 75th \\
\cline { 5 - 6 } & & & & & \\
Lending rate to NFCs & 19717 & 234 & 2.72 & 3.24 & 4.05 \\
Lending rate to HHs & 19841 & 229 & 3.28 & 3.99 & 4.91 \\
Bank bond yields & 9332 & 115 & 2.14 & 2.98 & 4.02 \\
Deposit rate & 19299 & 226 & 1.18 & 1.64 & 2.31 \\
\hline Sovereign debt exposure (over main assets) & 23935 & 258 & 0.83 & 4.05 & 8.09 \\
Non-performing loans (over RWA) & 7137 & 141 & 3.89 & 5.93 & 9.23 \\
CET1 capital ratio & 10264 & 147 & 8.89 & 9.54 & 10.59 \\
Leverage ratio & 23935 & 258 & 4.30 & 6.84 & 10.19 \\
Credit default swap (CDS) & 14891 & 160 & 0.95 & 1.27 & 2.00 \\
Capital and Reserve (bn) & 23935 & 258 & 0.73 & 2.23 & 6.05 \\
Total Assets (bn) & 23935 & 258 & 12.76 & 34.27 & 85.39 \\
\hline
\end{tabular}

Notes: the table reports the number of observations, the number of banks, the median and the 25th and 75 th percentile of the distribution of bank characteristics. 
Figure 1: Evolution of the policy rate and the distribution of lending rates

1
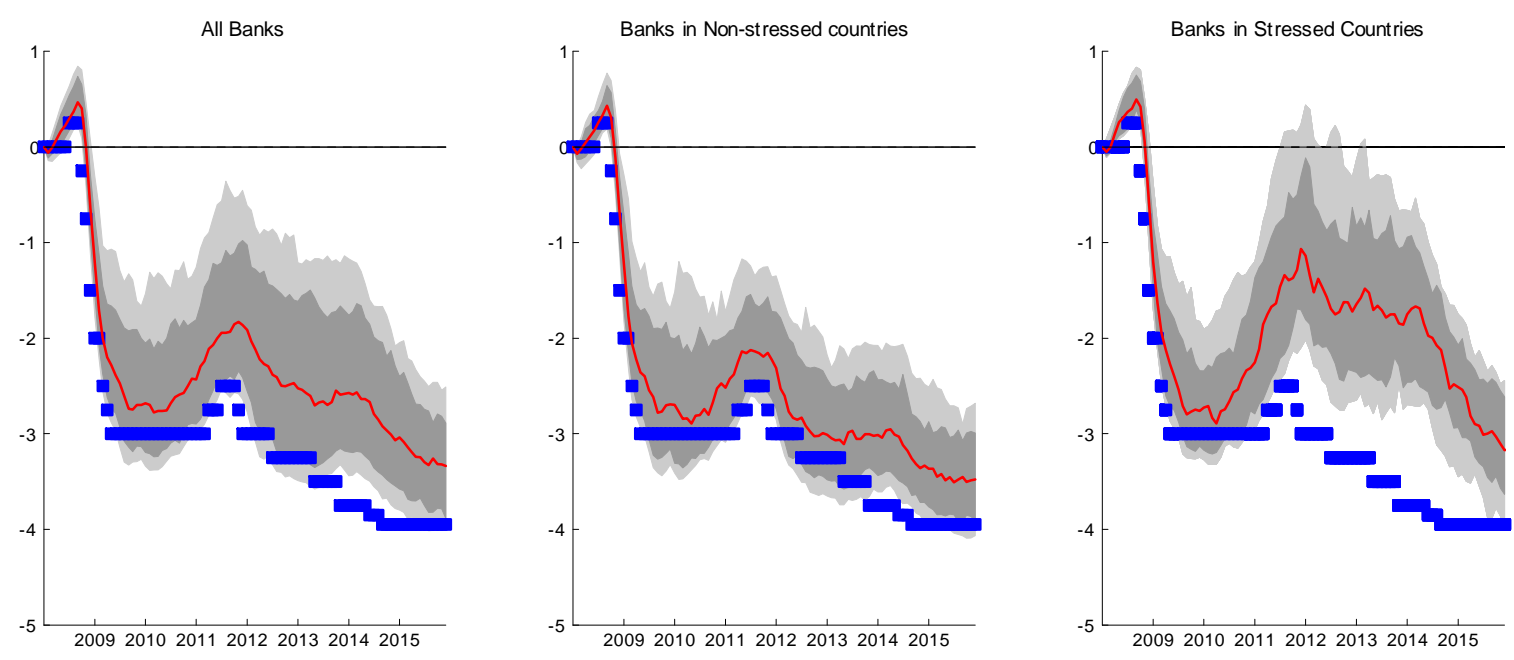

2.pdf

Notes: The figure shows the time evolution of the policy rate (segmented blue line), of the median value (red line), and of the $68 \%$ and $95 \%$ intervals of the distribution of lending rates to non-financial corporations(shaded areas) in deviation from the July 2007 value. Stressed countries are Greece, Cyprus, Italy, Spain, Ireland and Portugal. 
Figure 2: Responses of the lending rates and monetary pass- through

Panel A) Stressed vs Non-stressed countries
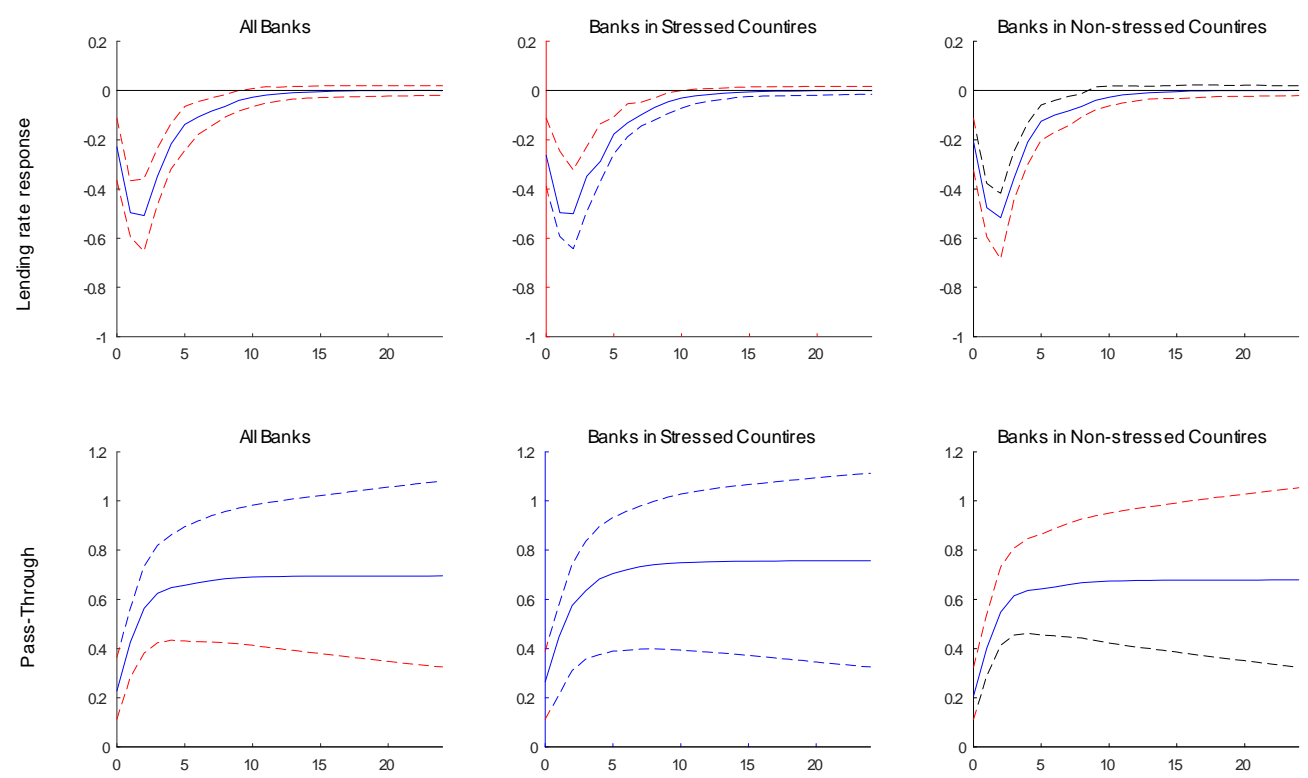

Panel B) Bidders vs. Non-bidders in the VLTRO
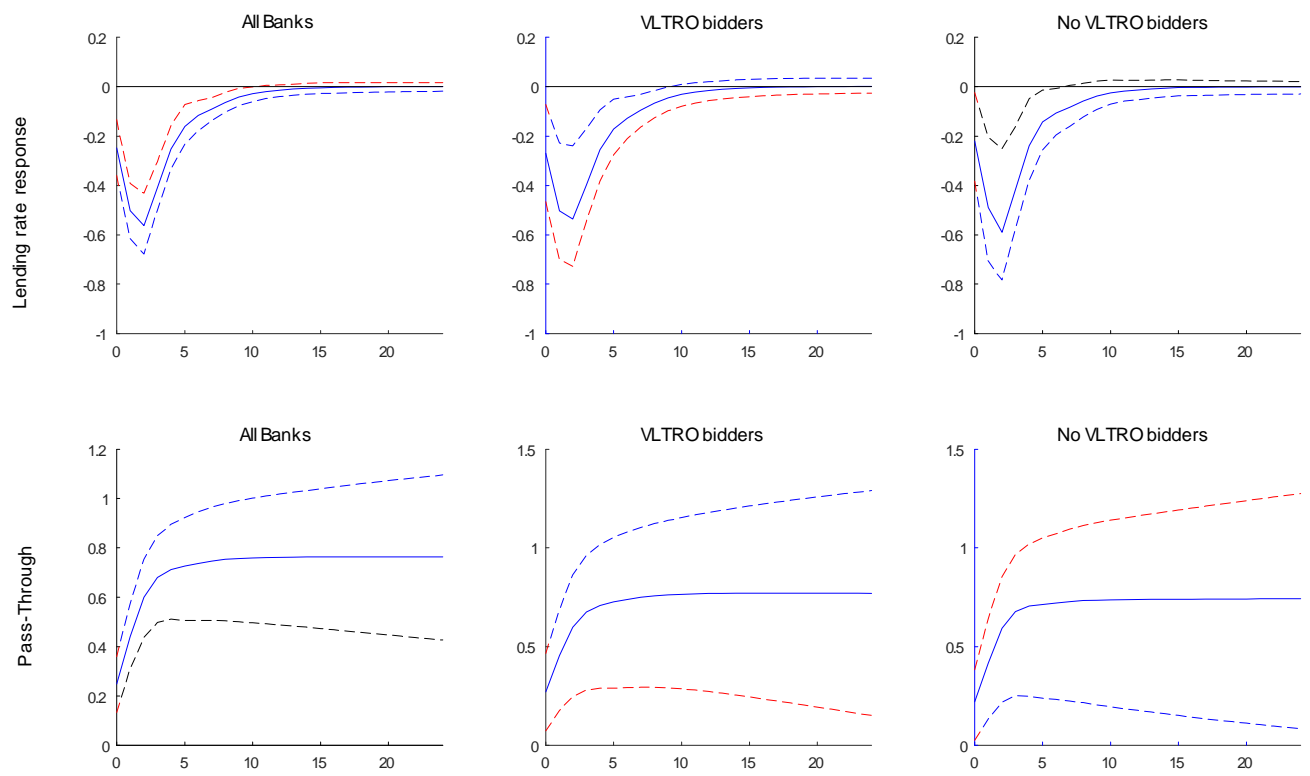

Notes: The figure shows the response of lending rates and the pass-through following a 100 basis points decline in the EONIA. Blue lines are the medians and red, dashed lines denote the 16th and 84th percentile of the posterior distribution. 
Figure 3: Monetary pass-through by bank characteristics, larger sample
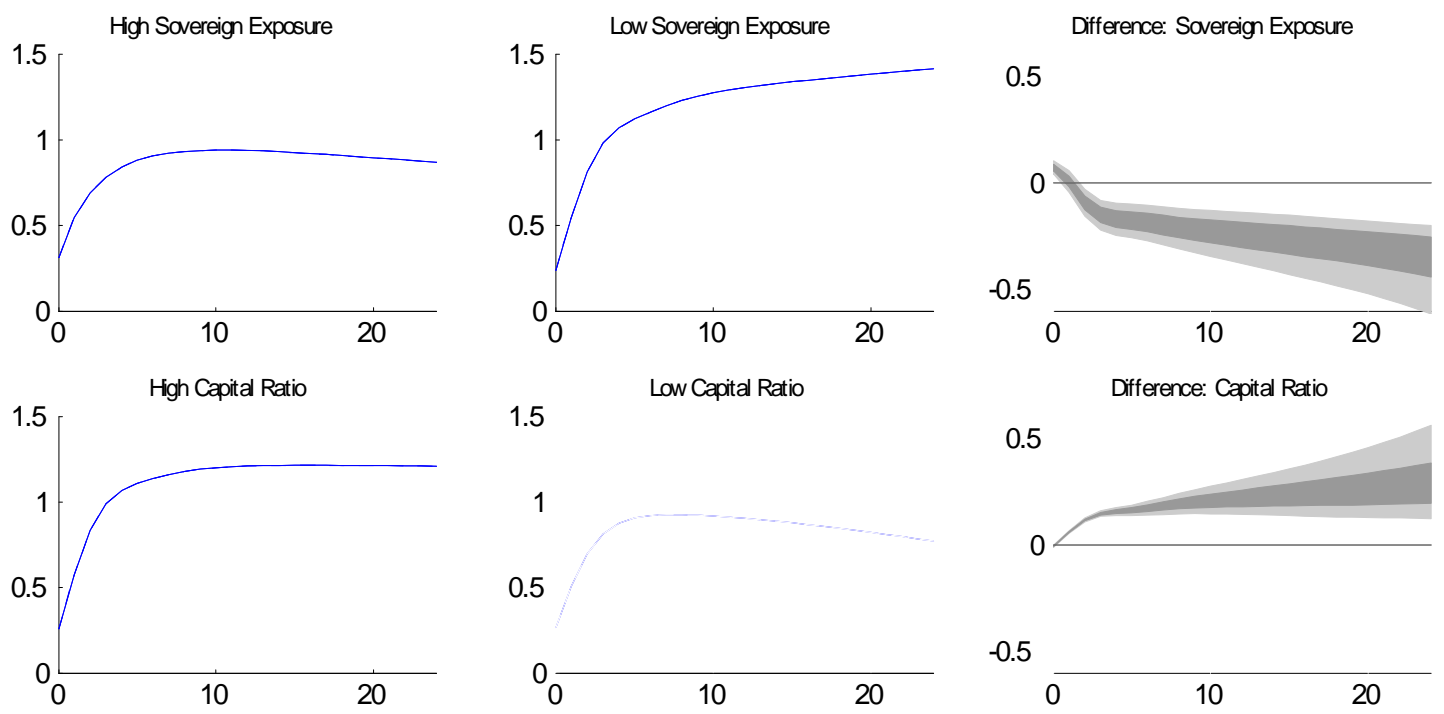

1.5

Difference: Capital Ratio

0.5

1

0.5

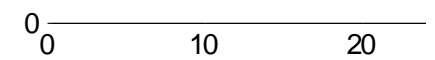

High Stable Funding

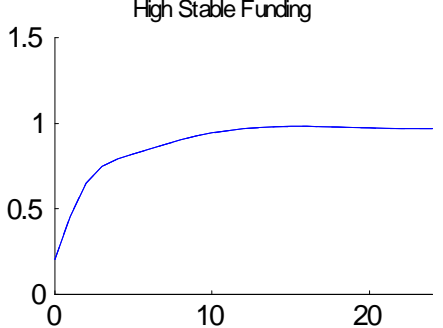

Low Stable Funding
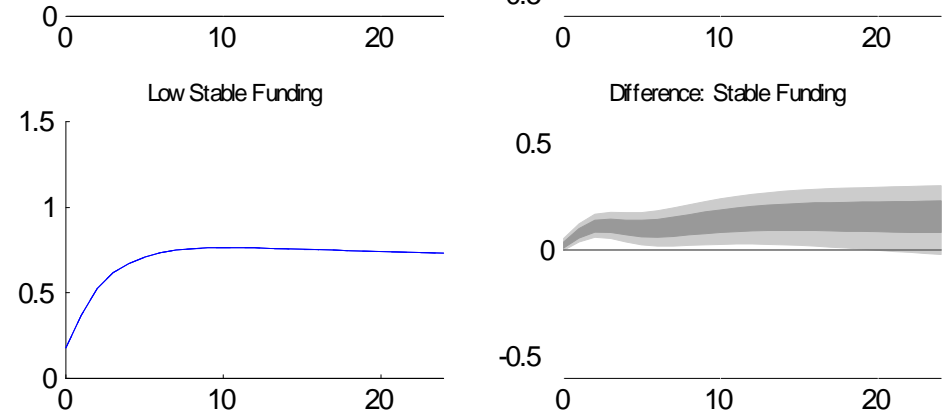

Difference: Stable Funding

0.5

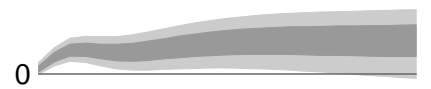

$-0.5$

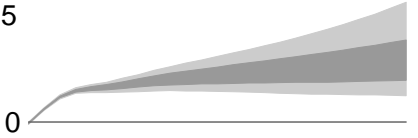

$-0.5$
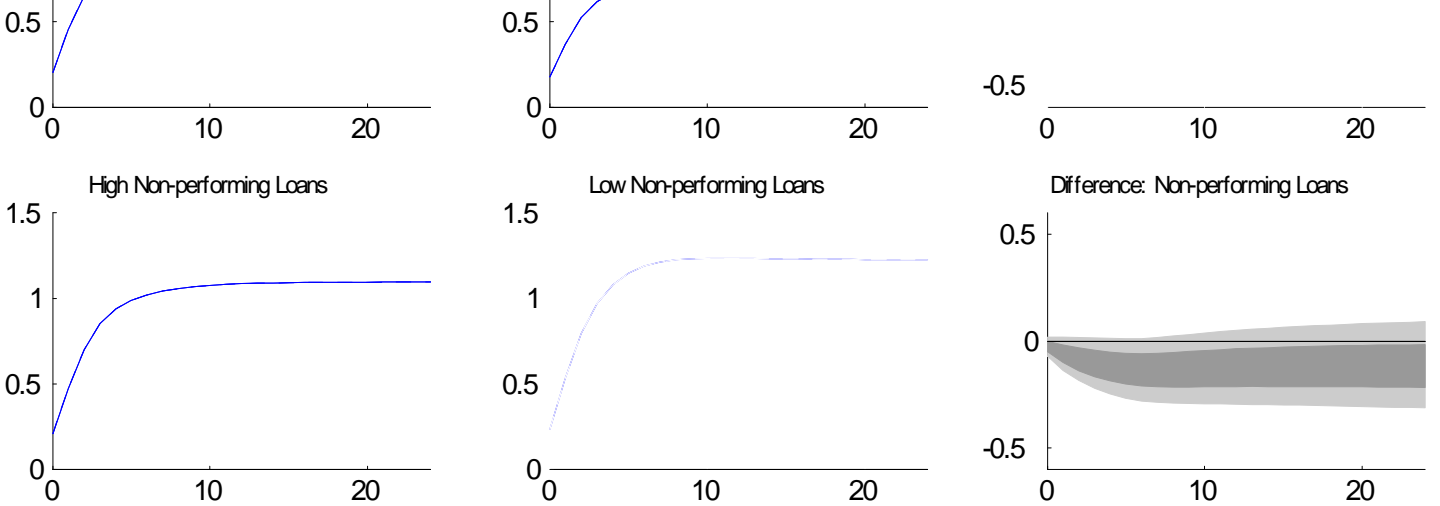

Notes: The figure shows the average responses in the top and bottom quartiles of the pass-through distribution sorted by bank characteristics. Shaded areas in the third column are the interquartile (dark grey), and the $95 \%$ (light grey) ranges. Posterior distributions are obtained using a VAR for each bank without the bank bond yield variable. 
Figure 4: Monetary pass-through by bank characteristics, smaller sample
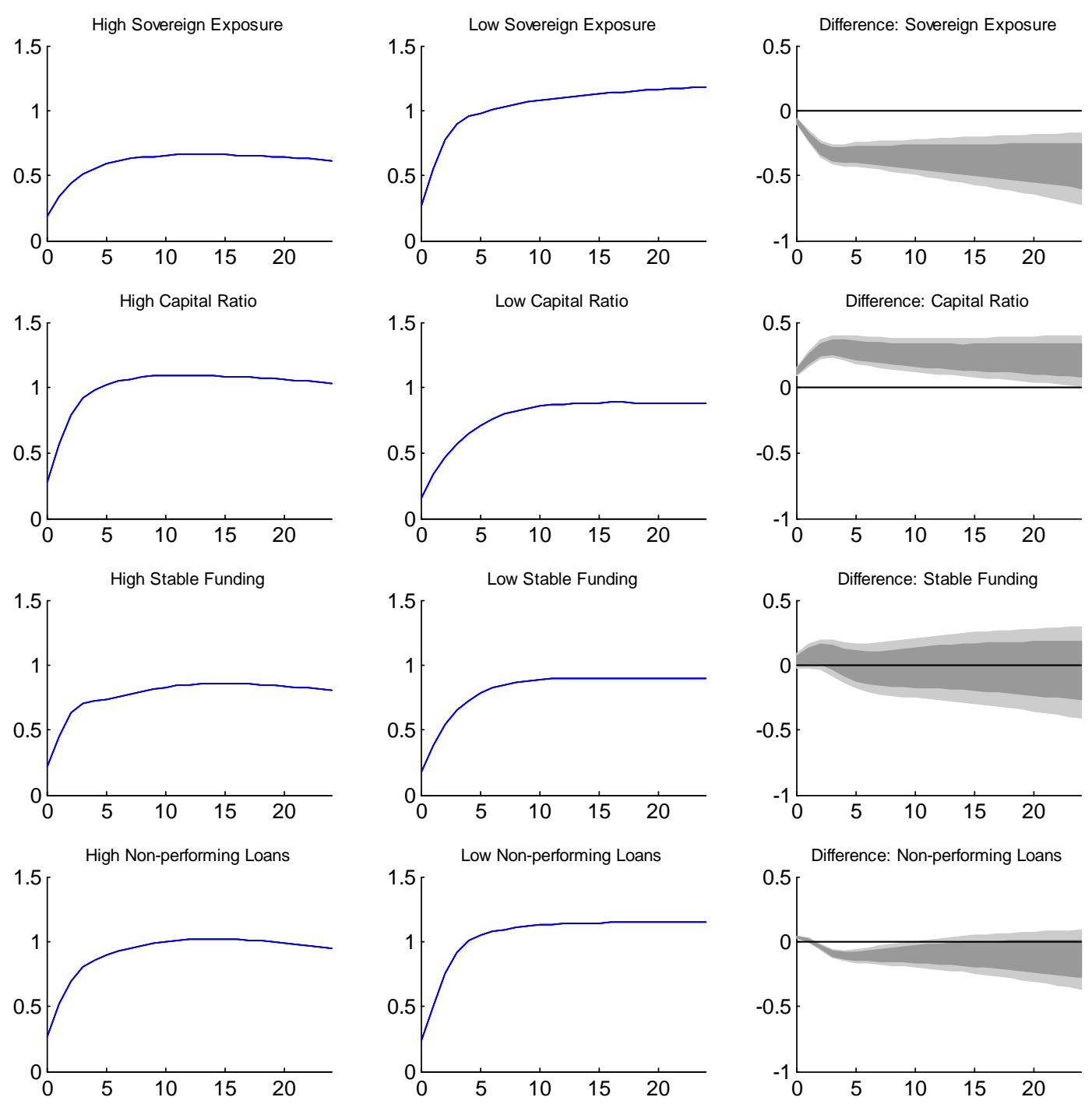

Notes: The figure shows the average responses in the top and bottom quartiles of the pass-through distribution sorted by bank characteristics. Shaded areas in the third column are the interquartile (dark grey), and the $95 \%$ (light grey) ranges. Posterior distributions are obtained using a VAR for each bank with the bank bond yield variable. 
Figure 5: Paths for the EONIA rate and bond yields consistent with non-standard measures
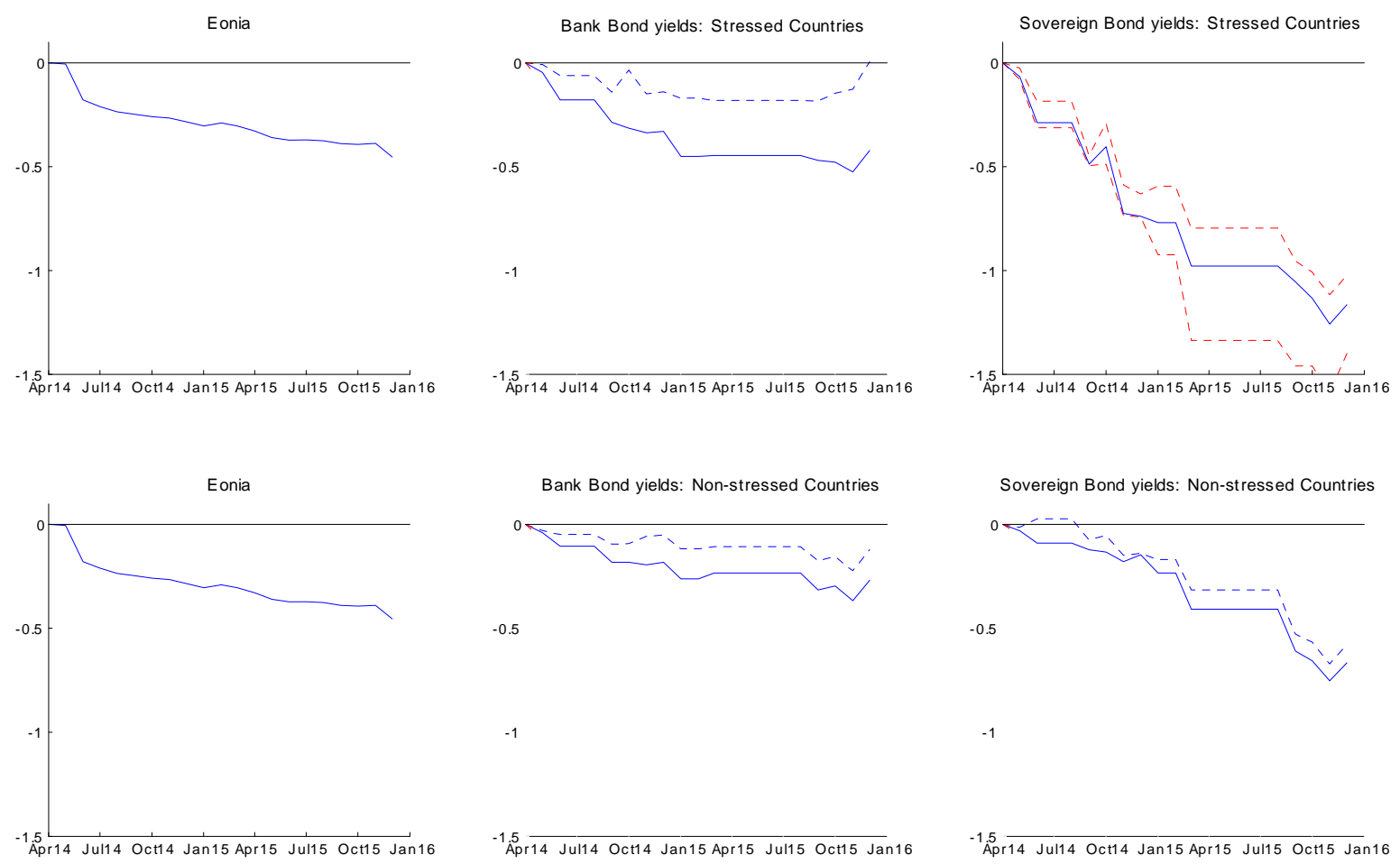

Notes: The figure reports the cumulated effects of non-standard measures on the Eonia rate (equal for all banks), on sovereign yields (equal for all banks operating in the same country) and on bank bond yields (different for each bank). 
Figure 6: Response of lending rates and monetary pass-through of non-standard measures
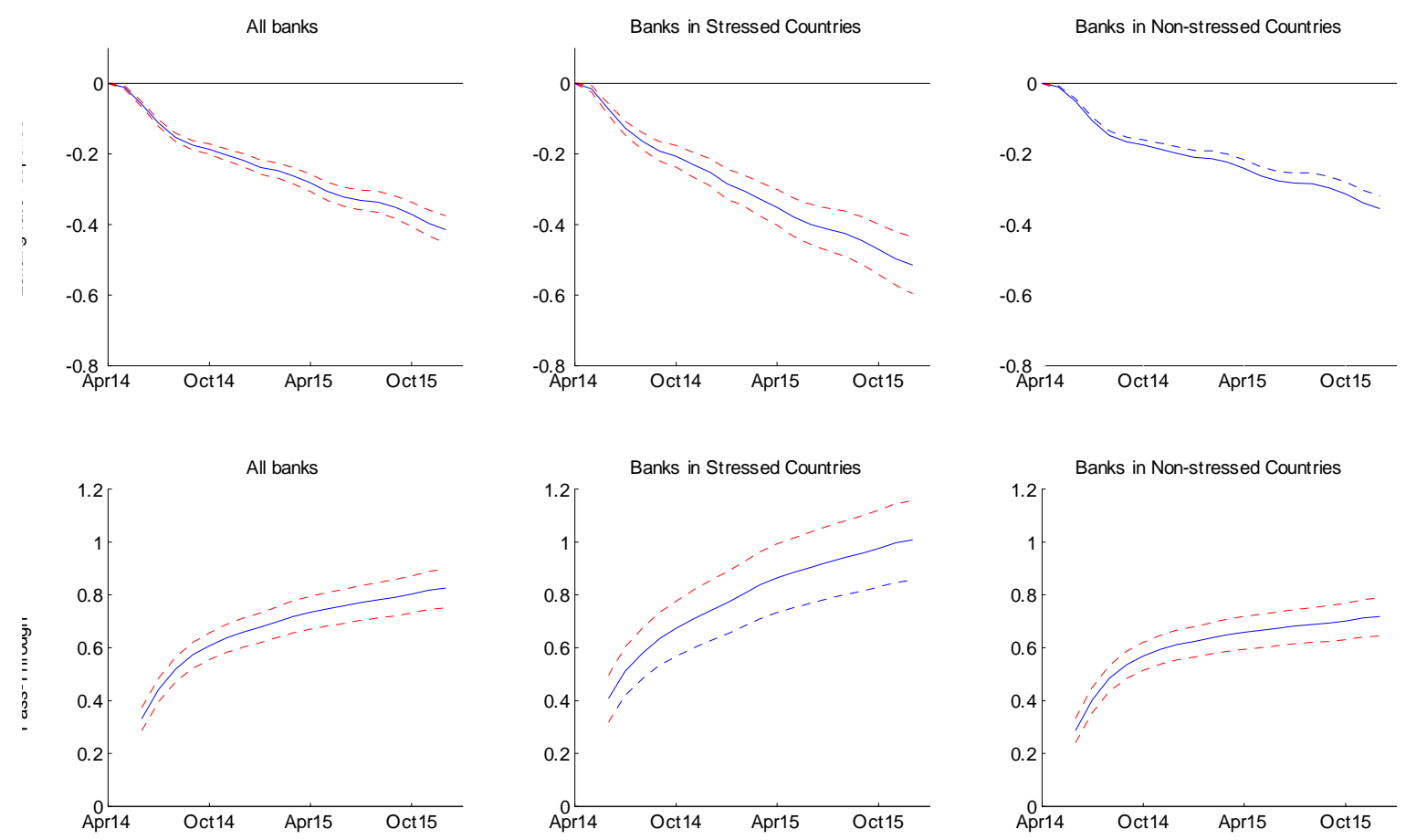

Notes: The blue solid line is the median; lines denote the 16th and 84th percentiles of the posterior distribution. Posterior distributions are obtained using a VAR for each bank without the bank bond yield variable. 
Figure 7: Lending rate differences by bank characteristics, larger sample
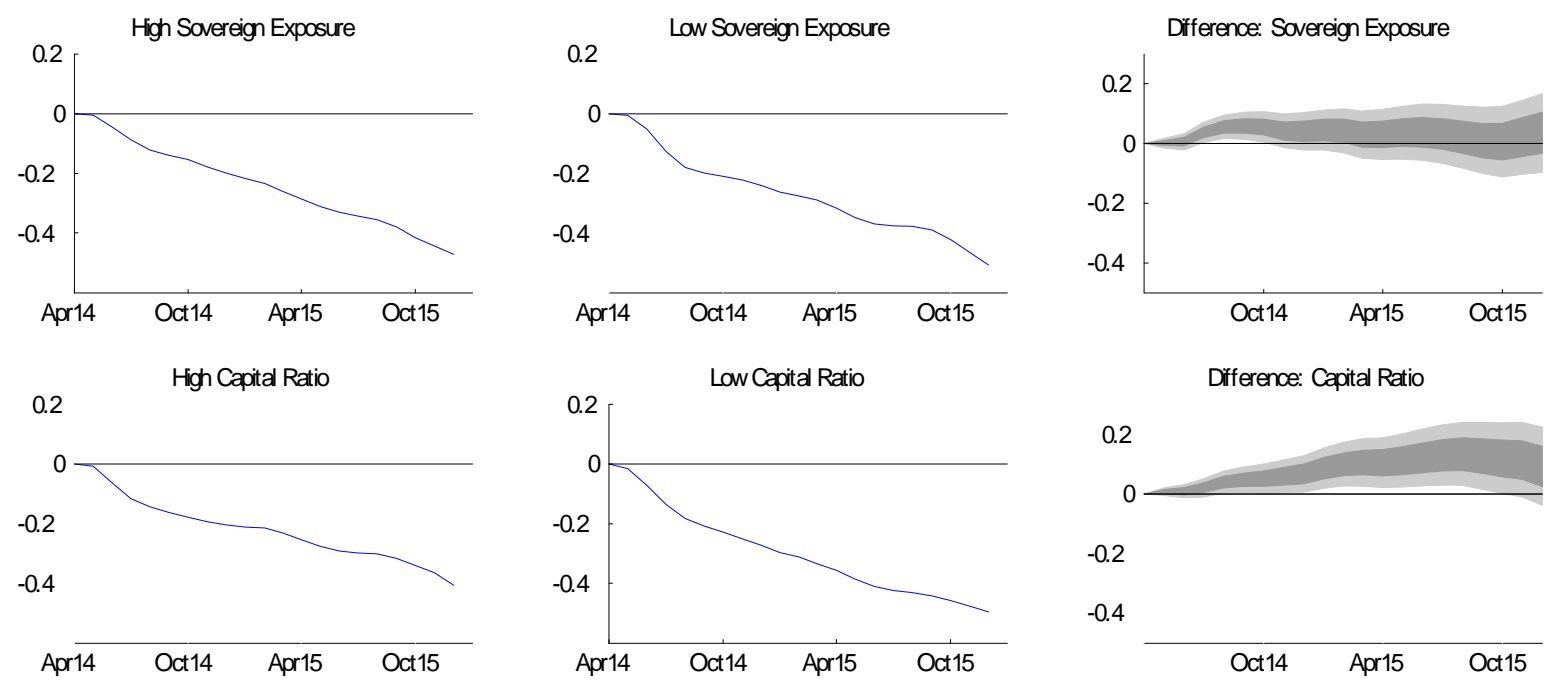

Difference: Capital Ratio
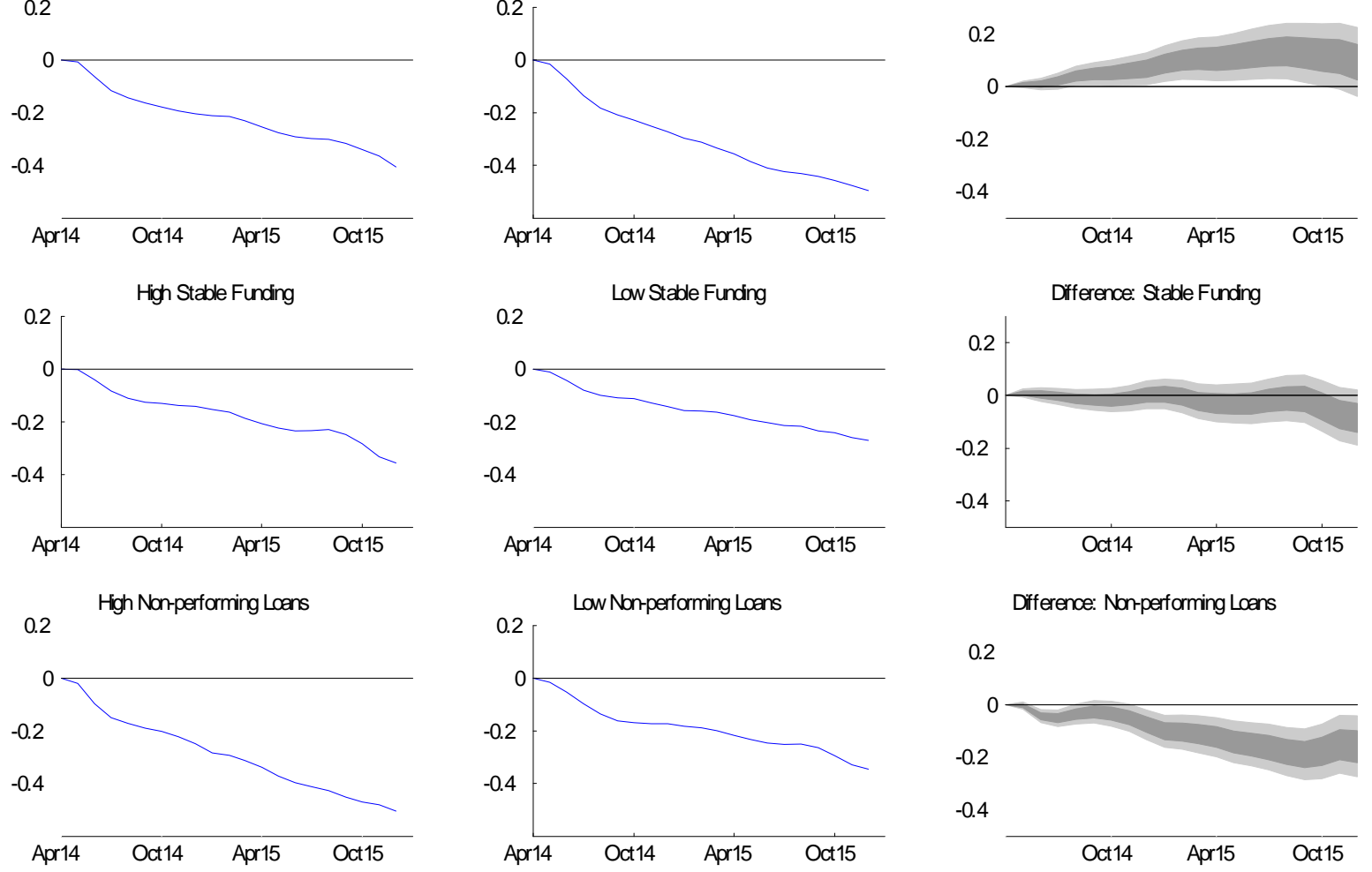

Notes: The figure shows the average responses in the top and bottom quartiles of the lending distribution sorted by bank characteristics. Shaded areas in the third column are the interquartile (dark grey), and the 95\% (light grey) ranges. Posterior distributions are obtained using a VAR for each bank without the bank bond yield variable. 
Figure 8: Lending rate differences by bank characteristics, smaller sample
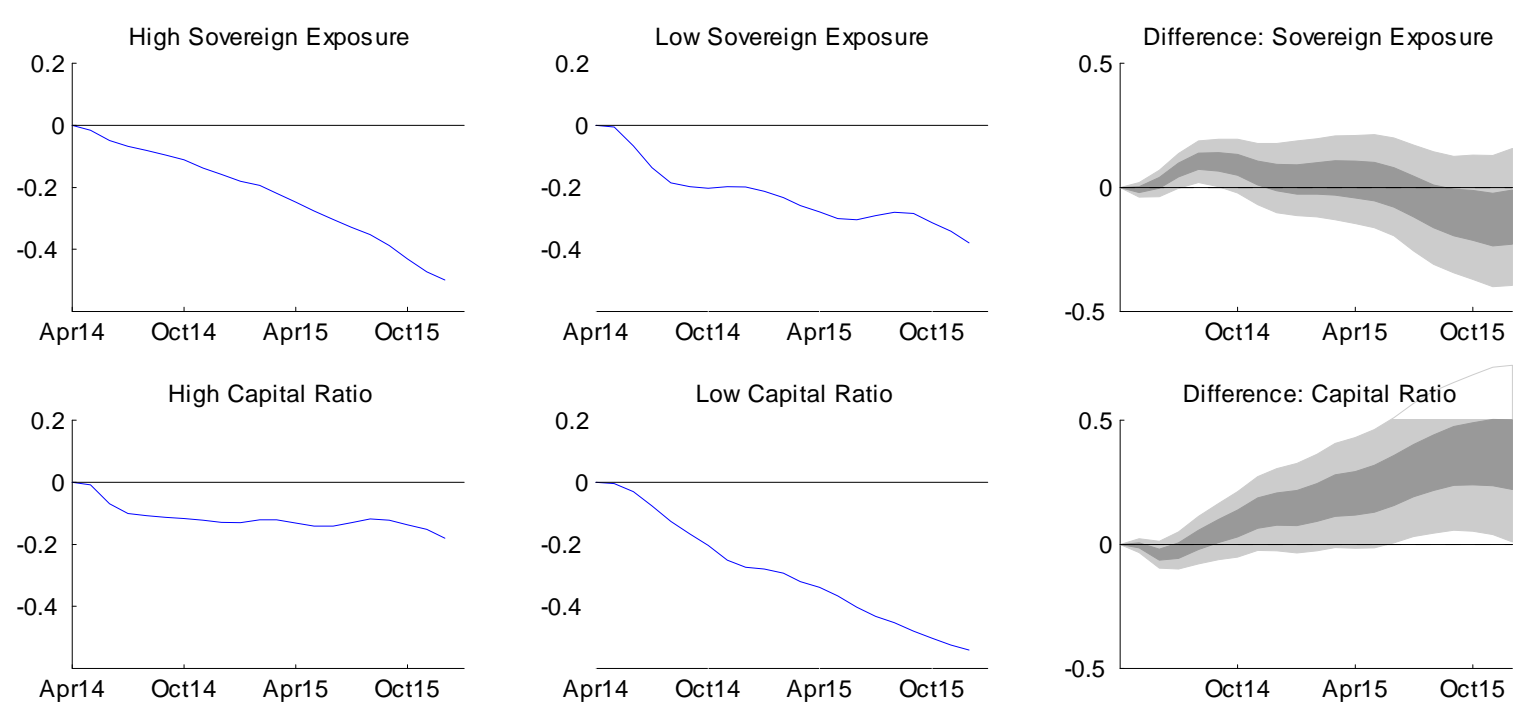

0.2
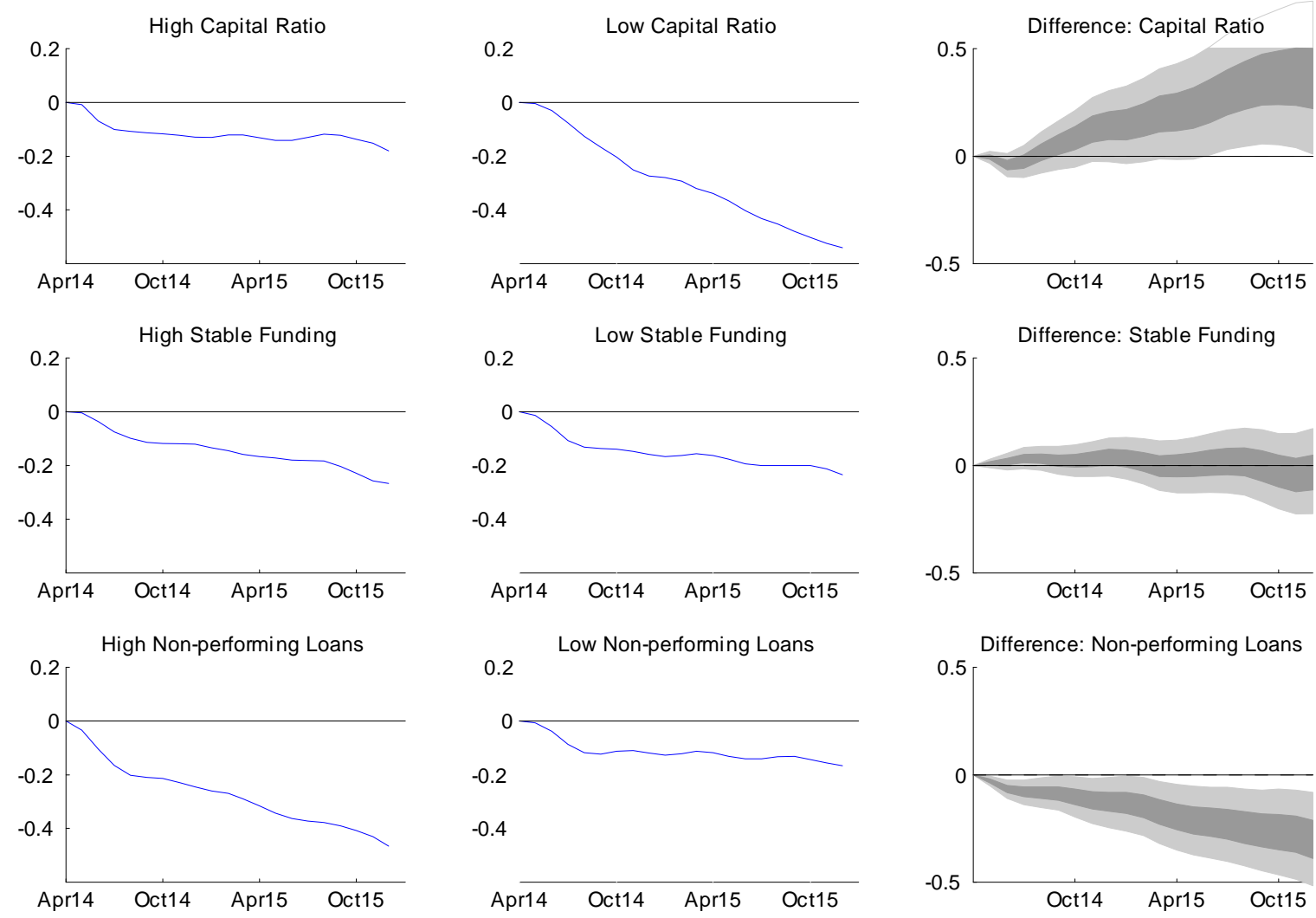

Notes: The figure shows the average responses in the top and bottom quartiles of the lending rate distribution sorted by bank characteristics. Shaded areas in the third column are the interquartile (dark grey), and the $95 \%$ (light grey) ranges. Posterior distributions are obtained using a VAR for each bank with the bank bond yield variable. 
Figure 9: Responses of lending margins by country
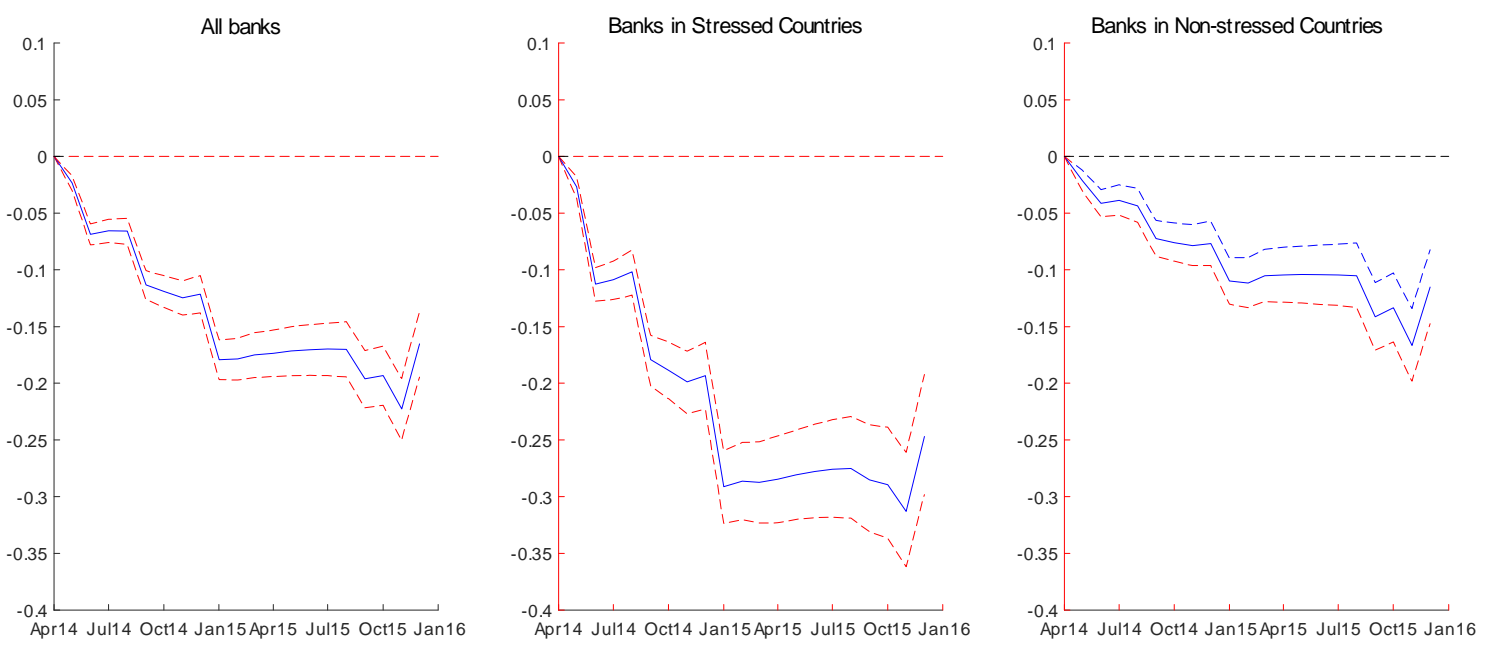

Notes: The figure shows the responses of lending margins depending on where banks operate. The blue solid line is the median; red, dashed lines denote the 16th and 84th percentiles of the posterior distribution. 
Figure 10: Dynamics of lending margins by bank characteristics
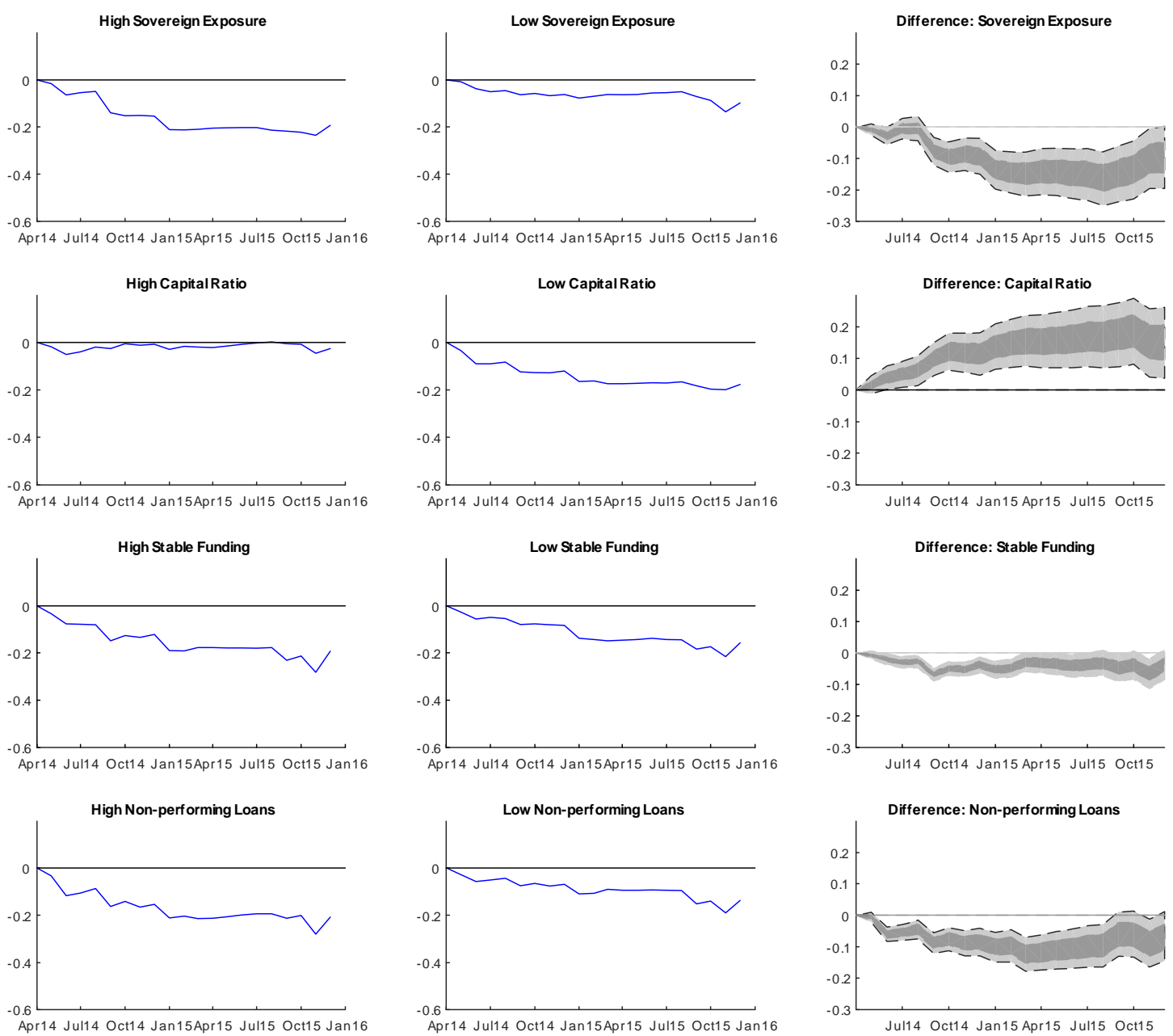

Notes: The figure shows the average responses in the top and bottom quartiles of the lending distribution sorted by bank characteristics. Shaded areas in the third column are the interquartile (dark grey), and the $95 \%$ (light grey) ranges. Posterior distributions are obtained using a VAR for each bank without the bank bond yield variable. 
Figure 11: Macroecomic effects of non-standard policies
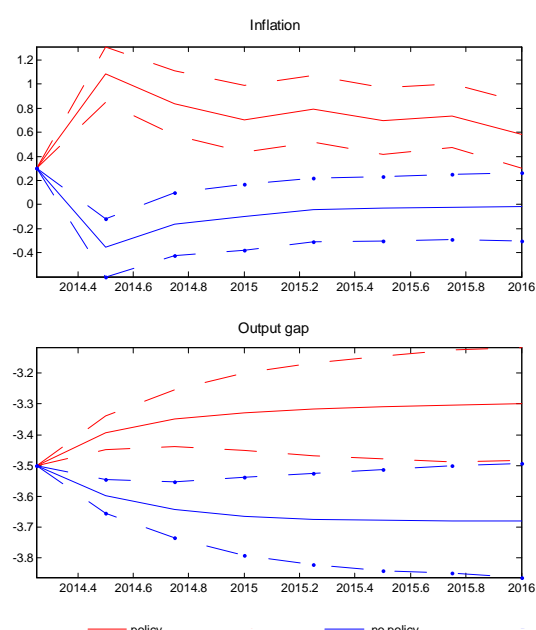

Notes: The figure shows the responses of the inflation and the output gap obtained with non-standard policies and the no-policy scenario (the policy rate and the lending rate remain unchanged at the 20014q1 level).

Figure 12: Perfect vs. imperfect pass-through dynamics
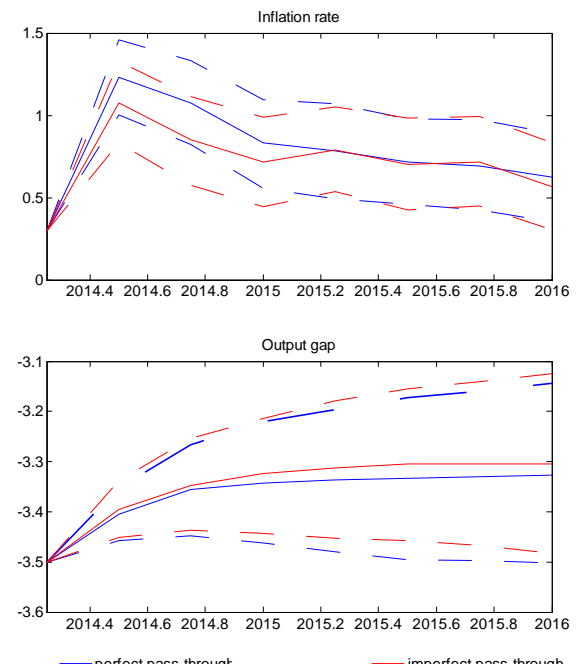

Notes: The figure shows the responses of the inflation and the output gap obtained with non-standard policies and under the assumption that the pass-through from the policy rate to the lending rate is perfect. 


\section{On-Line appendices}

\section{APPENDIX A: Additional Figures}

Table A1: Cross-country distribution of banks

\begin{tabular}{lcccc}
\hline & Head Institution & Domestic Subsidiary & Foreign Subsidiary & \multirow{2}{*}{ Total } \\
\hline \hline Austria & 6 & 2 & 1 & 9 \\
Belgium & 3 & - & 7 & 10 \\
Cyprus & 4 & - & 1 & 5 \\
Germany & 42 & 13 & 10 & 65 \\
Estonia & - & - & 4 & 4 \\
Spain & 19 & - & 4 & 26 \\
Finland & 5 & 22 & 4 & 9 \\
France & 10 & 2 & 6 & 38 \\
Greece & 4 & 1 & - & 6 \\
Ireland & 4 & 4 & 8 & 13 \\
Italy & 16 & - & 7 & 27 \\
Lithuania & - & - & 4 & 4 \\
Luxembourg & 3 & - & 8 & 11 \\
Latvia & 2 & - & 3 & 5 \\
Malta & 3 & - & 1 & 4 \\
Netherlands & 7 & - & 3 & 6 \\
Portugal & 4 & - & 2 & 5 \\
Slovenia & 3 & - & 2 & 3 \\
Slovakia & - & 47 & 78 & 260 \\
\hline Total & 135 & &
\end{tabular}

Notes: The table reports the number of banks in each country and their typology. 
Figure A1: Responses of lending rates to households and pass- through, overall, stressed and non-stressed countries
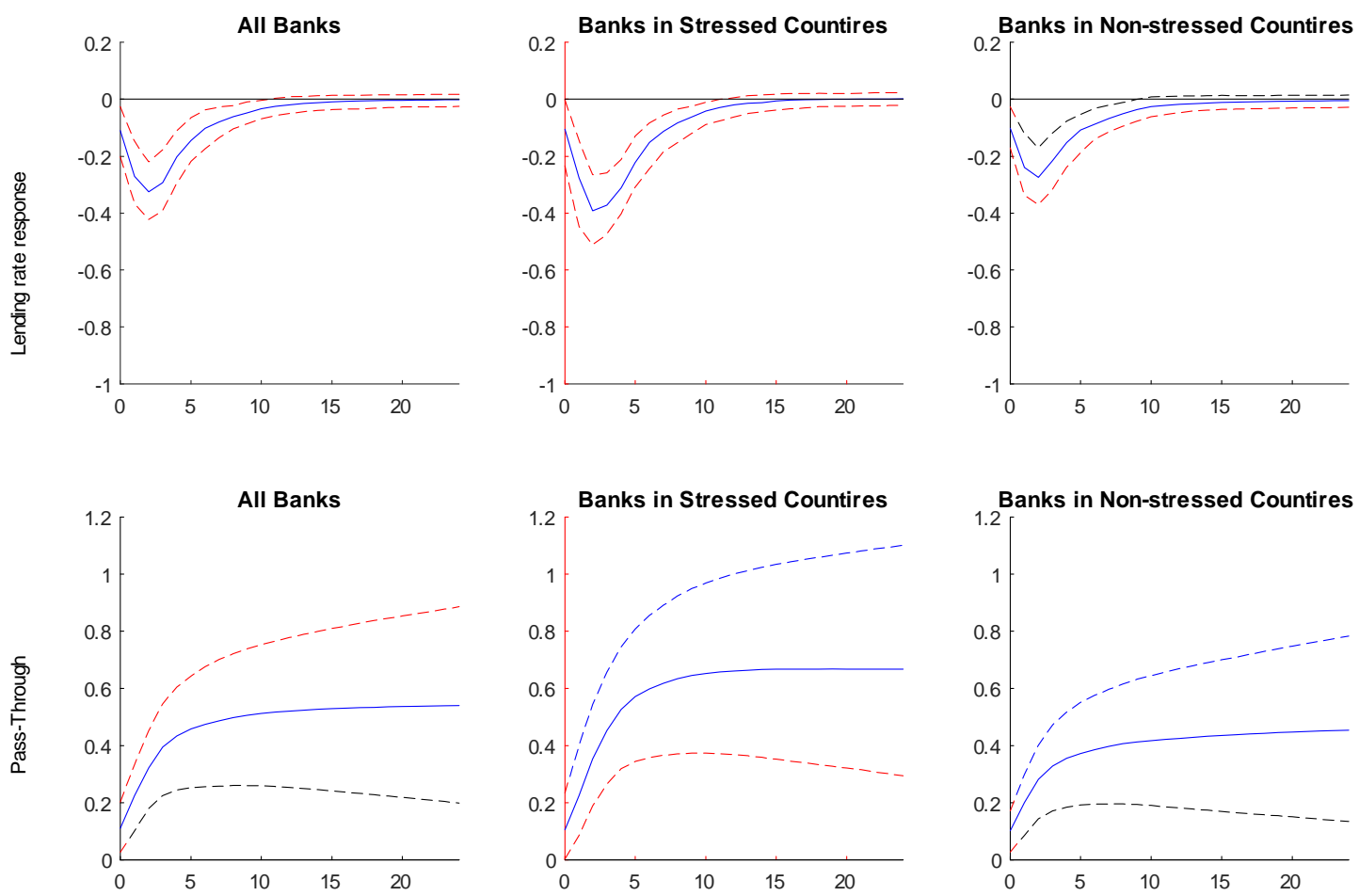

Notes: The figure shows the response of lending rates to households and the pass-through following a 100 basis point decline in the EONIA rate. Blue lines are the medians and red, dashed lines denote the 16th and 84th percentiles of the posterior distribution. 
Figure A2: Dynamics of the pass-through of lending rates to households by bank characteristics
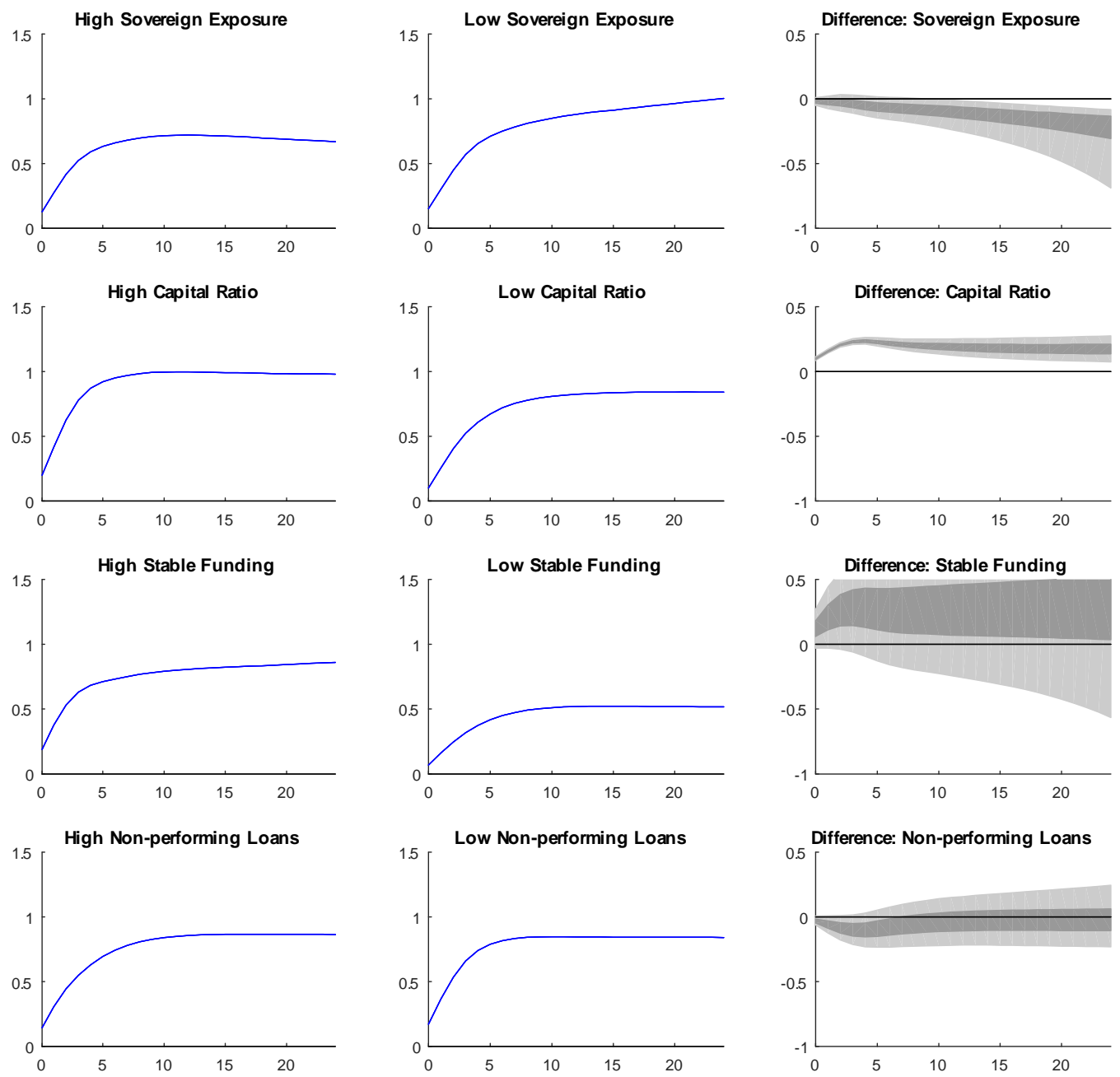

Notes: The figure shows the average responses in the top and bottom quartiles of the pass-through distribution sorted by bank characteristics. Shaded areas in the third column are the interquartile (dark grey), and the $95 \%$ (light grey) ranges. Posterior distributions are obtained using a VAR for each bank without the bank bond yield variable. Responses and pass-through are computed after a shock in the EONIA rate. 
Figure A3: Responses of lending rates to households and pass-through to non-standard mesures: overall,stressed and non-stressed countries
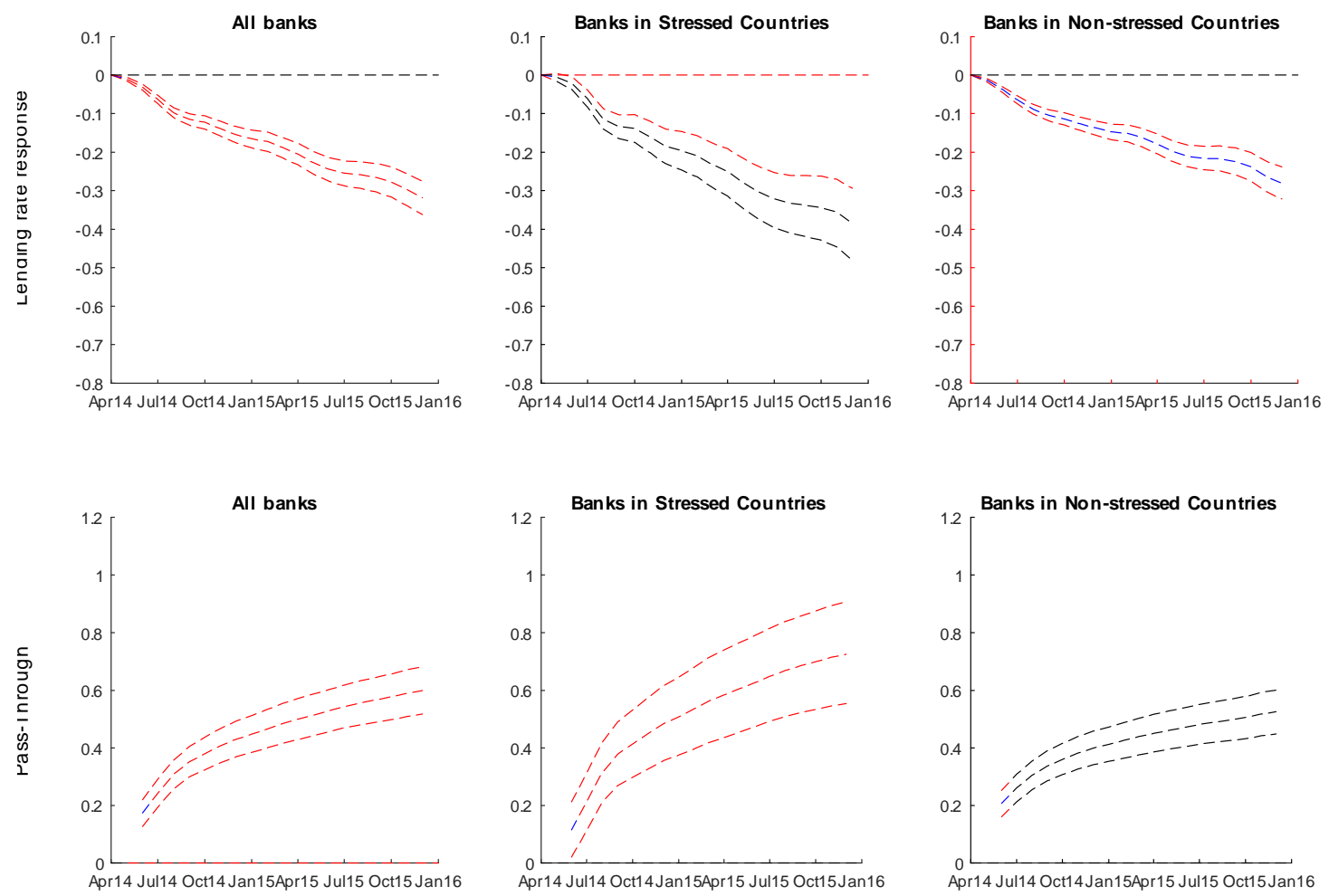

Note: the figure shows the responses of lending rates to households to non-standard measures depending on where banks operate. The blue solid line is the median; red, dashed lines denote the 16 th and 84th percentiles of the posterior distribution. 
Figure A4: Dynamics of the distribution of lending rates to household by bank characteristics, non standard measures
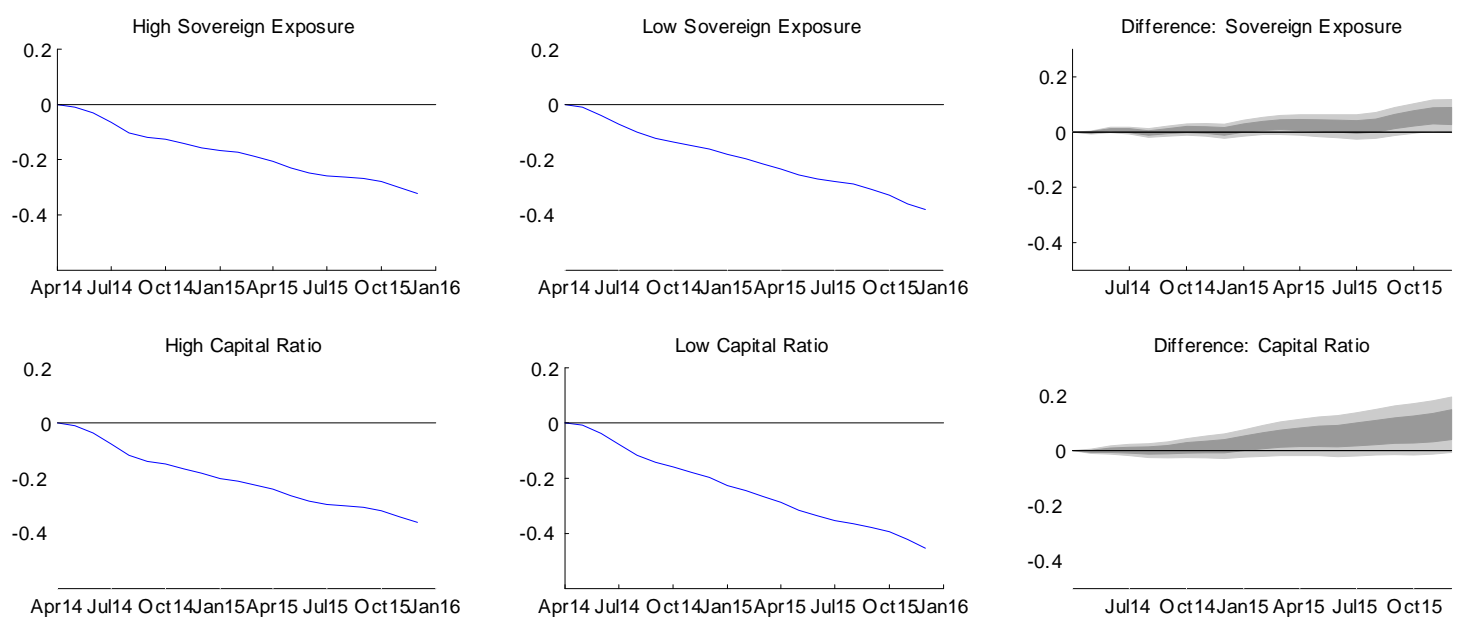

Difference: Capital Ratio

0.2

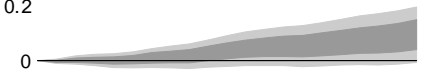

$-0.2$

$-0.4$

Apr14 Jul14 Oct14Jan15Apr15 Jul15 Oct15Jan16

Jul14 Oct14Jan15 Apr15 Jul15 Oct15

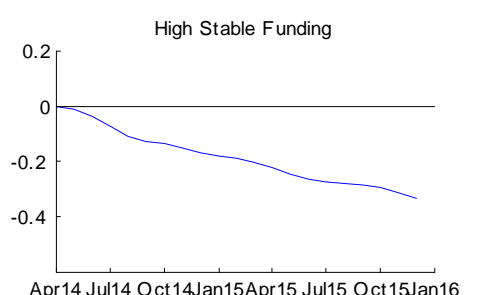

0.2

Low Stable Funding
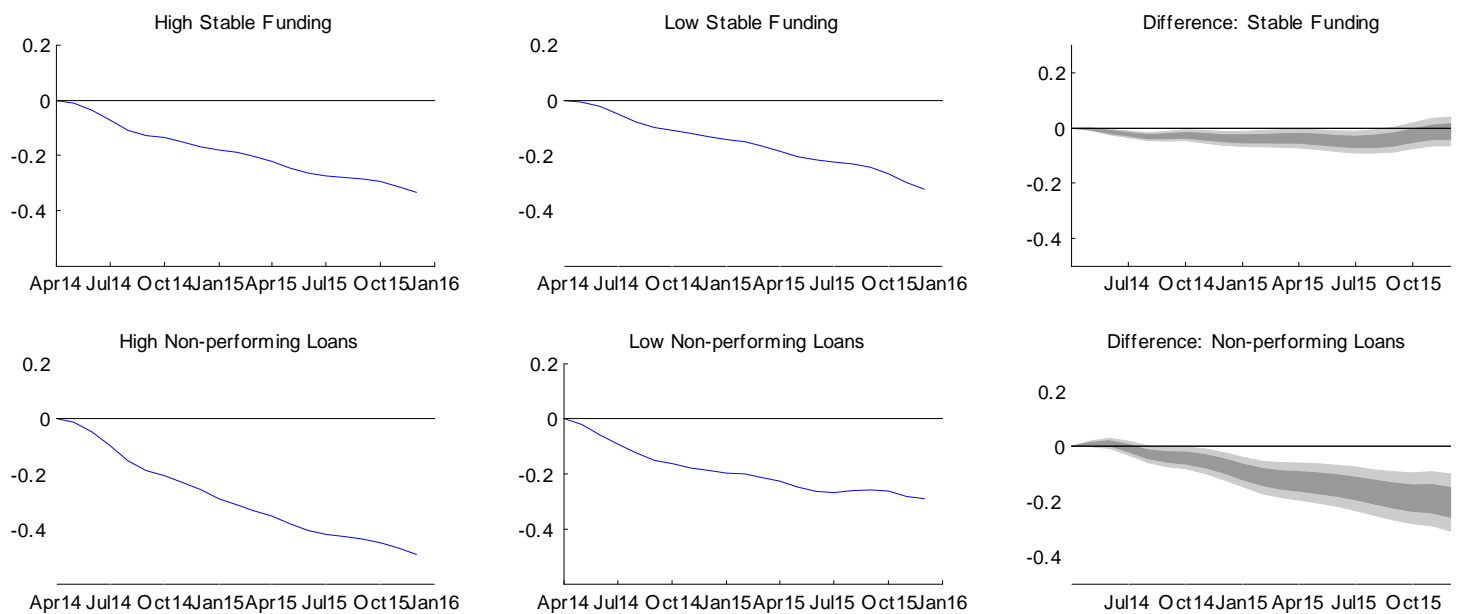

Difference: Non-performing Loans 0.2

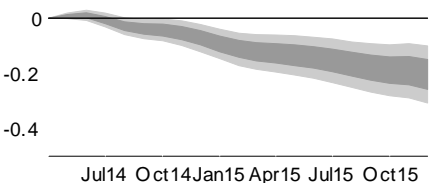

Notes: The figure shows the average responses in the top and bottom quartiles of the distribution of lending rates responses sorted by bank characteristics. Shaded areas in the third column are the interquartile (dark grey), and the $95 \%$ (light grey) ranges. Posterior distributions are obtained using a VAR for each bank without the bank bond yield variable. 
Figure A5: Dynamics of Lending Margins
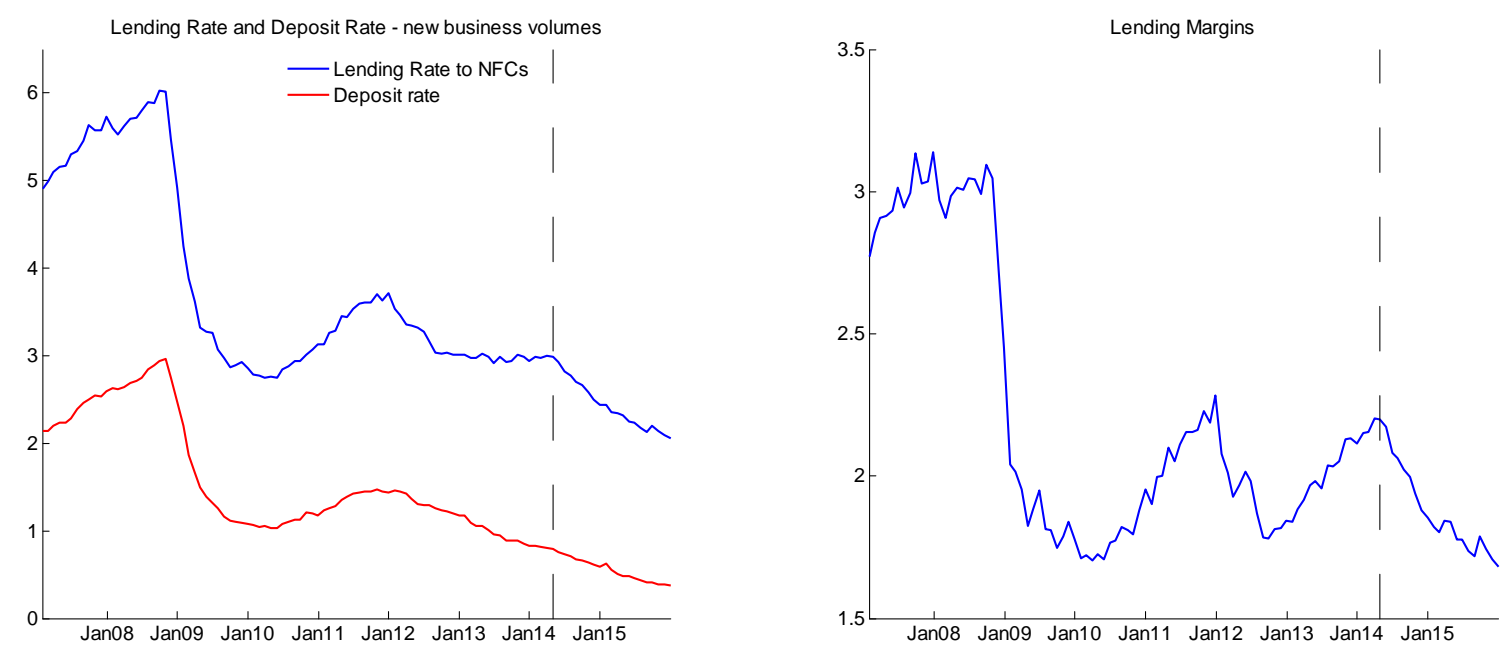

Notes: The figure shows the dynamics of average lending and deposit rates (left panel) and of the average lending margin (right panel). 
Figure A6: Effects of non-standard measures on different groups of banks Panel A) Lending to Non-financial corporations
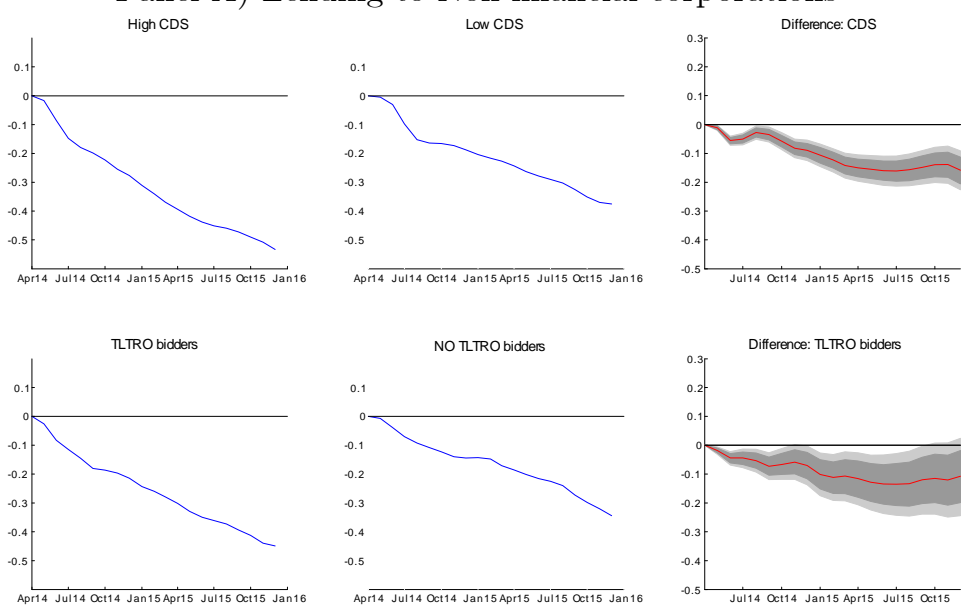

Panel B) Lending to Households
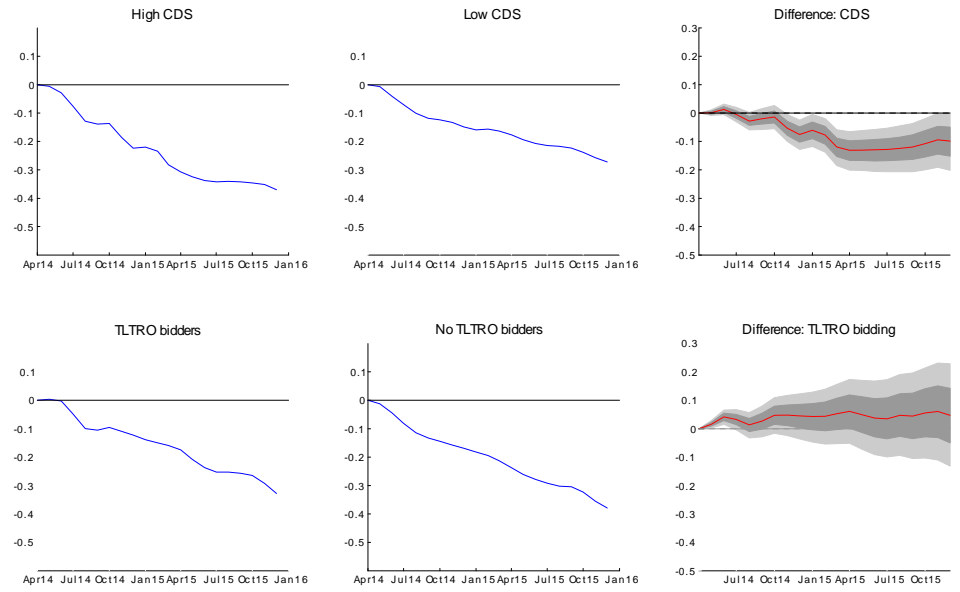

Notes: The figure shows the difference in the lending rate responses to non-standard policies according depending on balance sheet characteristics. The shaded areas are the interquartile (dark grey), and the $95 \%$ (light grey) ranges. 


\section{APPENDIX B: The model employed in section 7}

The model we use to measure the macroeconomic effects of non-standard measures is a standard New Keynesian model with sticky prices, habit persistence and working capital. In particular, we assume that the wage bill has to be paid before the firms receive the proceeds from selling the output. Thus, they have to borrow and marginal costs include both the cost of hiring labor and the cost of borrowing funds. We do not model the pricing decisions of the banks explicitly. Instead, we assume the existence of a spread between the policy rate and the lending rate, and between the lending rate and the deposit rate, which are calibrated to the samples under consideration. The equations of the model are:

$$
\begin{gathered}
w_{t}=\left(\frac{\sigma_{n}}{1-\alpha}+\frac{\sigma_{c}}{1-h}\right) y_{t}-\frac{h \sigma_{c}}{1-h} y_{t-1}-\frac{\sigma_{n}}{1-\alpha} z_{t}-\chi_{t} \\
y_{t}=\frac{1}{1+h} y_{t+1}+\frac{h}{1+h} y_{t-1}+\frac{1-h}{(1+h) \sigma_{c}}\left(\chi_{t+1}-\chi_{t}+r d_{t}-\pi_{t+1}\right) \\
\pi_{t}=\beta \pi_{t+1}+\frac{1-\alpha}{1-\alpha \theta} \frac{1-\beta \zeta)(1-\zeta)}{\zeta}\left(e^{\mu_{t}}+\left(r l_{t}-\pi_{t+1}\right)+w_{t}+\frac{\alpha}{1-\alpha} y_{t}-\frac{1}{1-\alpha} z_{t}\right) \\
r_{t}=\rho_{r} r_{t-1}+\left(1-\rho_{r}\right)\left(\rho_{p} \pi_{t}+\rho_{y} y_{t}\right)+e^{r_{t}} \\
r l_{t}=r_{t}+s p l_{t} \\
r d_{t}=r l_{t}+s p d_{t} \\
n_{t}=\frac{1}{1-\alpha}\left(y_{t}-z_{t}\right) \\
z_{t}=\rho_{z} z_{t-1}+e^{z_{t}} \\
\chi_{t}=\rho_{c} \chi_{t-1}+e^{c_{t}} \\
s p l_{t}=\rho_{l} s p l_{t-1}+e^{r l_{t}} \\
s p d_{t}=\rho_{d} s p d_{t-1}+e^{r d_{t}}
\end{gathered}
$$

where $w_{t}$ is the real wage, $n_{t}$ the number of hours worked, $y_{t}$ the output gap, $\pi_{t}$ the inflation rate, $r_{t}$ the nominal interest rate, $r l_{t}$ the nominal lending rate, $r d_{t}$ the nominal deposit rate, $z_{t}$ a technology shock, $\chi$ a preference shock, $s p l_{t}$ and $s p d_{t}$ lending and deposit spreads shocks, $e^{r_{t}}$ a monetary policy shock, $e^{\mu_{t}}$ a markup shock and $e^{r_{t}}, e^{\mu_{t}}, e^{r d_{t}}, e^{r l_{t}}, e^{r_{t}}, e^{c_{t}}, e^{z_{t}}$ are iid innovations to the exogenous shocks.

The parameters are as follows: $\sigma_{c}$ is the risk aversion coefficient, $h$ the coefficient of habit in consumption, $\sigma_{n}^{-1}$ the Frisch elasticity, $1-\alpha$ the share of labor in production, $\beta$ the discount factor, $\theta$ the elasticity of sustitution between goods in the final good bundle, $1-\zeta$ the Calvo probability of changing prices, $\rho_{r}$ the degree of interest rate smoothing, $\rho_{y}, \rho_{\pi}$ the response 
parameters in the policy rule to output gap and inflation, and $\rho_{z}, \rho_{c}, \rho_{l}, \rho_{d}$ the persistence of the exogenous shocks.

In the exercises, we set $\sigma_{c}=1, h=0.8, \sigma_{n}=1.5, \beta=0.99, \alpha=0.66, \theta=1.9, \zeta=0.66, \rho_{r}=$ $0.9, \rho_{y}=0.0, \rho_{p}=0.5, \rho_{z}=0.9 ; \rho_{c}=0.8 ; \rho_{l}=0.8 ; \rho_{d}=0.65$. We assume that the steady state levels of the output gap, inflation and the nominal rate are 1.5, 2.0, 3.0, respectively, the averages one obtained for the euro area in the 2000-2007 period. We also assume that the steady state level of the lending rate is 4.0 (in line with our data). The steady state deposit rate is 3.2 , in line with the average deposit spreads in the euro area for the period 2000-2007.

The counterfactuals exercises are conducted as follows. To measure the effect on inflation of having a low pass-through for the period 2009q1-2014q1, we compute the average differences in inflation when we input in the model the actual path of the policy rate and either the path of the median lending rate or a path for the lending rate equal to the path of the policy rate plus the steady state lending spread.

To measure the impact of non-standard policies on output gap and inflation for the period 2014q2-2015q4, we input in the system the path of the policy rate due to announcement surprises (reported in figure 6) and either the median path of the lending rate induced by announcement surprises (reported in figure 7) and the median path for the deposit rate implied by the lending margin responses (reported in figure 11) or the path of the lending (deposit) rate obtained assuming that the median value of the distribution of lending (deposit) rate at 2014q1 would persist unchanged until 2015q4.

To measure the dynamic consequence of reestablishing a perfect monetary pass-through via non-standard measures, we compute the evolution of the output gap and inflation during the 2014q2-2015q4 period inputting in the model the actual path of the policy rate and either a path for lending (deposit) rate equal to the path of the policy rate plus the steady state lending (deposit) spread or the median path of the distribution of lending (deposit) rates produced by the non-standard policy announcements.

For the last two exercises the system starts at the values observed in 2014q1. In particular, inflation at that date is set at 0.3 percent and the output gap is set at -3.5 percent, as reported by Eurostat. 
Centre for Applied Macro - and Petroleum economics (CAMP)

will bring together economists working on applied macroeconomic issues, with special emphasis on petroleum economics.

BI Norwegian Business School

Centre for Applied Macro - Petroleum economics (CAMP)

N-0442 Oslo

http://www.bi.no/camp 